\title{
The influence of chlorothalonil on the activity of soil microorganisms and enzymes
}

\author{
Małgorzata Baćmaga' · Jadwiga Wyszkowska' • Jan Kucharski ${ }^{1}$
}

Accepted: 10 July 2018 / Published online: 1 September 2018

(c) The Author(s) 2018

\begin{abstract}
As one of the most widely used pesticides in agriculture, chlorothalonil can pose threat to soil ecosystems. Therefore, the impact of this substance on the development of microbiological and biochemical properties of the soil as well as on the growth of spring wheat was evaluated. The study was conducted with two soils (loamy sand with $\mathrm{pH}_{\mathrm{KCl}} 5.6$ and sandy loam with $\mathrm{pH}_{\mathrm{KCl}} 7.00$ ), to which fungicide was used in the following doses: $0.00,0.166$ (recommended dose), 1.660, and $16.60 \mathrm{~m} \mathrm{~kg}^{-1}$ dry matter of soil (DM of soil). In addition, we determined the effectiveness of fertilizing substances (Lignohumat Super and Bioilsa N 12.5) in the restoration of soil homeostasis and chlorothalonil degradation in the soil. Chlorothalonil caused modifications in the count and biological diversity of soil microorganisms. It stimulated the growth of heterotrophic bacteria and actinobacteria, and inhibited the growth of fungi. This pesticide was a potent inhibitor of dehydrogenase, catalase and acid phosphatase activities. It showed variable effects on urease and alkaline phosphatase. The fungicide also a reduction the yield of dry matter of the aboveground parts of spring wheat. It should, however, be noted that these changes in the soil environment occurred after the introduction of higher doses of chlorothalonil. The fertilizing substances used contributed to enhanced microbial and biochemical activities of soils, while they did not significantly affect plant yields. The Bioilsa N 12.5 preparation was effective in chlorothalonil degradation, while Lignohumat Super reduced the degradation rate of the tested fungicide. Based on the conducted experiment, an ecological risk assessment of chlorothalonil was made by estimating the changes occurring in the soil environment evaluated through the microbiological and biochemical analyses of the soil.
\end{abstract}

Keywords Chlorothalonil $\cdot$ Soil $\cdot$ Contamination $\cdot$ Fertilizing substances $\cdot$ Microbial and biochemical activity $\cdot$ Degradation

\section{Introduction}

The intensive development of agriculture and the increased food demand have led to massive applications of plant protection products. Fungicides are among the most important and most commonly used groups of pesticides, which are applied to protect plants against fungal diseases. They contain one or more active substances, the action of which in fungal cells includes: arrest of mitosis and cell division; inhibition of respiration, synthesis of nucleic acids, amino acids and proteins, lipids and cell membranes, as well as cell wall melanin, but also inhibition of sterol and

Jadwiga Wyszkowska

jadwiga.wyszkowska@uwm.edu.pl

1 Department of Microbiology, University of Warmia and Mazury in Olsztyn, Plac Łódzki 3, Olsztyn 10-727, Poland cell wall biosynthesis, and signal transduction (Petit et al. 2012; Ijaz et al. 2015). Fungicides primarily allow obtaining high plant yields, but they can also exert negative effects on the environment, including the soil, by disrupting its homeostasis. Multiple applications of these preparations during the growing season make them not only effective in eliminating target organisms but also in destroying other non-targeted organisms. The accumulation of fungicides in the soil increases the risk of negative effects on organisms present in this ecosystem as well as on biological processes (Devashree et al. 2014). Microorganisms involved in soilforming processes, organic matter transformation, stabilization of soil aggregates and the circulation of elements play an important role in maintaining adequate soil fertility. Interaction of soil microorganisms with other organisms (e.g. earthworms, nematodes, plants) present in the soil can significantly affect the quality and health of plants, and thus indirectly influence the level of agricultural production and sustainability of soil ecosystems (Shahgholi 2014). 
Chlorothalonil is one of the most commonly used fungicides in the world. This is a synthetic compound from the group of chlorinated benzonitriles. It was first registered in the United States in 1966. In fungus cells, it leads to the inhibition of enzymes responsible for cellular respiration (Shi et al. 2011). Chlorothalonil is very effective in protecting plants against fungal diseases caused mainly by Phytophthora infestans and Alternaria solani, and prevents germination of fungal spores (Leitao et al. 2014). It is toxic to aquatic organisms (fish, invertebrates), birds, and also to humans, as it may cause inflammation of the skin, eyes and gastrointestinal disorders (Wang et al. 2011). Chlorothalonil is also considered a carcinogen (Wang et al. 2011). Leitao et al. (2014) reported its half-life to range from 0.3 to 87 days in the soil under laboratory conditions, while from 18 to 70 days in field conditions. According to Wang et al. (2011), the half-life decomposition of chlorothalonil in the soil ranged from 19 to 30 days. However, this substance can be detected in the soil for 100 days or even 1 year because it is often repeatedly applied during the growing season in some regions (Chaves et al. 2008). Due to its widespread use in crop plant protection, its residues are often detected in agricultural crops, fruits, vegetables, in the soil and water environment and in the air (Chaudhuri et al. 2013). Chlorothalonil can undergo chemical and microbiological degradation in the soil environment. Its degradation results in the formation of many metabolites : 4-hydroxy-2,5,6-trichloroisophthalonitrile, 1,3-dicarbamoyl-2,4,5,6-tetra chlorobenzene, 2,5,6-trichloro-4-methoxy isophthalonitrile, 1carbamoyl-3-cyano-4-hydroxy2,5,6-trichlorobenzene, 2,4,5trichloroisophthalonitrile, 2,5,6-trichloro-4 (methylthio)isophthalonitrile, isophthalonitrile (Chaves et al. 2008).

The negative effect of fungicides on the soil environment can be minimized by the use of suitable fertilizing substances such as compost, manure, straw or sewage sludge (Kadian et al. 2008; Pimmata et al. 2013). Soil supplementation with such substances often leads to the stimulation of soil microorganisms that may exhibit the ability to degrade fungicides present in this environment (Adams et al. 2015).

The use of fungicides may pose serious risk to the natural environment surrounding us. It may be manifested by the disruption of the correct structure and functions of soil ecosystems. According to Saha et al. (2016) and Sułowicz and Piotrowska-Seget 2016, literature still lacks detailed information on the effects of active substances of fungicides on the biological properties of soil. Due to the risk of soil ecosystems contamination with fungicides, this study was conducted to determine the impact of chlorothalonil on the biological properties of the soil. In addition, the efficacy of Lignohumat Super and Bioilsa N 12.5 fertilizing substances was evaluated in homeostasis restoration of soil treated with chlorothalonil.

\section{Materials and methods}

\section{Soil material}

Soil material was derived from the Didactic and Experimental Center in Tomaszków near Olsztyn, Poland. The characteristics of the area have been given in the work of Borowik et al. (2017). Soils used in the experiment belonged to Eutric Cambisols, and in terms of texture were classified as loamy sand and sandy loam. The physicochemical properties of the soils given in Table 1 were determined according to methods described by Carter (1993).

\section{Fungicide}

Gwarant $500 \mathrm{SC}$ is a contact fungicide designed to protect wheat, potato, tomato and cucumber against fungal diseases. It is a concentrate in a suspension for dilution with water, produced by Arysta LifeScience, which was authorized for marketing in Poland in 2011. In wheat protection, it is applied at a dose of $1.0 \mathrm{dm}^{3} \mathrm{ha}^{-1}, 1 \mathrm{dm}^{3}$ of this preparation contains $500 \mathrm{~g}$ chlorothalonil, which is one of the compounds from the group of chloronitriles. Considering that, $0.166 \mathrm{mg}$ of chlorothalonil was applied per $1 \mathrm{~kg}$ of soil.

\section{Soil fertilizer amendments}

Lignohumat Super and Bioilsa N 12.5 fertilizing substances were introduced at the manufacturer's recommended doses due to possible negative effects of the chlorothalonil on the

Table 1 General characteristics of experimental soil

\begin{tabular}{|c|c|c|c|c|c|c|c|c|c|c|}
\hline \multirow[t]{2}{*}{ Type of soil } & Sand $(50-2000 \mu \mathrm{m})$ & Silt $(2-50 \mu \mathrm{m})$ & $\begin{array}{l}\text { Clay }< \\
2 \mu \mathrm{m}\end{array}$ & $\mathrm{C}_{\mathrm{org}}$ & $\mathrm{N}_{\text {total }}$ & $\mathrm{pH}_{\mathrm{KCl}}$ & HAC & EBC & CEC & $\mathrm{BS} \%$ \\
\hline & $\%$ & & & $\mathrm{~g} \mathrm{~kg}^{-1}$ & & & & $\mathrm{mMol}$ & $(+) \mathrm{kg}^{-1} \mathrm{DM}$ of soil & \\
\hline Loamy sand & 80.50 & 18.00 & 1.50 & 10.00 & 0.58 & 5.60 & 18.66 & 40.00 & 58.66 & 68.19 \\
\hline Sandy loam & 72.00 & 21.00 & 7.00 & 7.05 & 0.86 & 7.00 & 8.000 & 111.0 & 119.00 & 93.28 \\
\hline
\end{tabular}

$C_{\text {org }}$ organic carbon content, $N_{\text {total }}$ total nitrogen content, $H A C$ hydrolytic acidity, $E B C$ exchangeable base cations, $C E C$ cation exchange capacity, $B S$ base saturation 
biological properties of the soil. Lignohumat Super is a substance produced by Agrarius. It contains $90 \%$ of humic substances (including $80-85 \%$ salts of humic acids and $15-20 \%$ of fulvic acids) and $10 \%$ of macronutrients and micronutrients $(9 \%$ potassium, $3 \%$ sulfur, $0.02 \%$ iron, $0.12 \%$ copper, $0.012 \%$ manganese, $0.12 \%$ zinc, $0.15 \%$ boron, $0.15 \%$ molybdenum, $0.12 \%$ cobalt, trace amounts of calcium and silicon). The dose recommended by the manufacturer of this preparation is between 0.5 and $1.0 \mathrm{~kg} \mathrm{ha}^{-1}$. In the experiment, Lignohumat Super was used at a dose of $0.333 \mathrm{mg} \mathrm{kg}^{-1}$.

In turn, Bioilsa N 12.5 is a controlled-release nitrate fertilizer for the fertilization of orchard, vegetable, and agricultural plants. It is produced by Natural Crop and contains: organic nitrogen-12.5\% (including dissolved organic nitrogen-5\%), organic carbon of biological origin $-40 \%$ (including extractable organic carbon-95\%), and organic matter-70\%. The dose recommended by the manufacturer for cereals ranges between 400 and $700 \mathrm{~kg}$ ha ${ }^{-1}$. In the experiment, this preparation was applied at a dose of $233 \mathrm{mg} \mathrm{kg}^{-1}$.

\section{Procedure and conditions of the experiment}

The pot experiment was performed in five replicates in polyethylene pots of $3.5 \mathrm{dm}^{3}$ volume containing $2.7 \mathrm{~kg}$ of loamy sand with $\mathrm{pH}_{\mathrm{KCl}} 5.6$ and sandy loam with $\mathrm{pH}_{\mathrm{KCl}}$ 7.0. On the day of starting the experiment, $\mathrm{CaCO}_{3}$ was added to loamy sand $\left(\mathrm{pH}_{\mathrm{KCl}}\right.$ 5.6) in the amount equilibrating the hydrolytic acidity at the level of $1.5 \mathrm{HAC}$ (hydrolytic acidity) to neutralize the soil. The Gwarant 500 SC fungicide was used in the experiment, which, was used at the following doses (based on the active substance): 0 (soil without fungicide addition), 0.166 (manufacturer's recommended dose), 1.660 (10-fold the recommended dose), and $16.60 \mathrm{mg} \mathrm{kg}^{-1}$ (100-fold the recommended dose). The aqueous solution of the fungicide was applied; $1 \mathrm{~cm}^{3}$ of the solution per $1 \mathrm{~kg}$ dry matter of soil. Three water solution were prepared on the day when the experiment had been established and applied once in the tested doses to the soil. $1 \mathrm{~cm}^{3}$ of particular solution contained: $0.333 \mathrm{~mm}^{3}$ (optimal dose), $3.33 \mathrm{~mm}^{3}$ (10-fold higher dose), and $33.33 \mathrm{~mm}^{3}$ (100-fold higher dose) of the fungicide. Mineral fertilizer doses were applied to the soil in the following quantities (calculated per pure component in $\mathrm{mg} \mathrm{kg}^{-1}$ ): $\mathrm{N}-100$ (urea), $\mathrm{P}-44$ (potassium dihydrogen phosphate), $\mathrm{K}-100$ (potassium dihydrogen phosphate ${ }_{+}$potassium chloride), $\mathrm{Mg}-25$ (magnesium sulfate heptahydrate). Lignohumat Super and Bioilsa N 12.5 fertilizing substances were introduced at the manufacturer's recommended doses, due to possible negative influences of the fungicide on the biological activity of the soil. The fertilizing substances were introduced once to the soil material on the day of experiment establishment.
Lignohumat Super was used in the form of a water suspension prepared from a granulate. $1 \mathrm{~cm}^{3}$ of the water solution contained $0.333 \mathrm{mg}$ of the tested fertilizing substance. In turn, Bioilsa N 12.5 was added to soil in the form of a granulate in weighted portions of $233 \mathrm{mg} \mathrm{kg}^{-1}$. The tested crop was spring wheat of cultivar Arabella. The soil moisture was maintained at $50 \%$. Soil humidity was maintained at a stable level by its continuous monitoring. Its level was checked every day and adjusted with distilled water. The vegetation pot experiment was conducted in polyethylene pots in five replications for each combination (giving a total of 120 pots): four doses of chlorothalonil, two types of soil, three types of fertilizers, five replications. Before analyses made on two sampling moments (day 19 and 50), soil samples were collected from each combination (from five polyethylene pots for each combination) and mixed into a collective sample of $500 \mathrm{~g}$ that was thoroughly homogenized. To obtain samples, the soil material was sampled from each pot across its whole depth. Thus, prepared collective samples were used for determinations of the microbiological and biochemical properties of soil, that were made in three replications for each sample. Residues of chlorothalonil were determined on day 19 in soil specimens with the highest fungicide dose $\left(16.60 \mathrm{mg} \mathrm{kg}^{-1}\right)$, while the yield of spring wheat on day 50 .

\section{Microbiological analyses}

Microbiological analyses were performed in three replicates at two experimental time points (day 19 and 50) using the plate method. The count of actinobacteria, fungi, and heterotrophic bacteria was determined according to the procedure described in the work of Kucharski et al. (2016). Observations of microbial colony growth were carried out for 9 days at 3-day intervals, when the count of microorganisms was determined. Based on the count of microorganisms, the count of microbial colonies growing at certain time intervals $\left(\mathrm{K}_{\mathrm{s}}\right)$ was calculated, according to the formula given in the work by Tomkiel et al. (2015).

\section{Enzymatic analyses}

The enzymatic activity of soil was determined on 19 day and 50 day after the start of the experiment. The biochemical analyses included determination of the activities of: acid phosphatase, alkaline phosphatase, catalase, dehydrogenases, and urease. To determine the activity of soil enzymes, the samples were incubated in a thermostat (with no access to light) at a temperature of $37^{\circ} \mathrm{C}$. The activity of soil enzymes, with the exception of catalase, was determined using a Perkin-Elmer Lambda 25 (Massachusets, USA) spectrophotometer. The exact methodology for 
determining the activity of soil enzymes is provided in the paper of Borowik et al. (2017).

\section{Determination of chlorothalonil residues in the soil}

Residues of chlorothalonil in soil samples were determined with the GC-EC method (gas chromatography with an electron capture detector). Chlorothalonil content in soil samples was determined using an Agilent 7890 A (Santa Clara, Kafifornia, USA). Data were received and processed by the Chemstation (Hewlett-Packard, version A.10.2) software. Quantitative determination was carried out by comparing peak heights obtained in soil samples against the standards used (Łozowicka et al. 2016). Chlorothalonil detection limit reached $0.005 \mathrm{mg} \mathrm{kg}^{-1}$, whereas analytical recovery value ranged from 70 to $75 \%$.

\section{Spring wheat development}

Spring wheat, cultivar Arabella, was used as a test plant to evaluate chlorothalonil phytotoxicity. After 7 days from the start of the experiment, spring wheat was sown in the pots in the quantity of 25 seeds per pot. When the spring wheat was sprouting (BBCH 10-the first leaf emerges from the leaf sheath), a thinning was performed, leaving 12 plants in the pot. Soil moisture was maintained at 50\% throughout the vegetation period. The plants according to the $\mathrm{BBCH}$ scale (scale of plant growth stage) were harvested at the end of the heading stage of spring wheat (BBCH 59-all spikelets emerge from the sheath, the head is completely visible). For this purpose, the above-ground parts were cut and then dried at a temperature of $65^{\circ} \mathrm{C}$ for 5 days. After thorough drying of the plant material, the dry plant biomass was determined on the basis of which the resistance (RS) of spring wheat in the soil treated with chlorothalonil was calculated according to the formula described by Orwin and Wardle (2004).

\section{Statistics}

The statistical analyzes were performed using Statistica 12.5 software (Statsoft, Inc, Statistica 2017). The $\eta^{2}$ coefficient was used to calculate the percentage of observed variability of the analyzed factors (ANOVA at a significance level of $P<0.05$ ). Pearson's linear correlation coefficients were calculated between the variables studied. Homogeneous groups were determined $(P<0.05)$ by the Tukey's test using ANOVA variance analysis. The responses of microorganisms to chlorothalonil action and soil fertilizing substances were presented as a Ward dendrogram using cluster analysis. In turn, the activity of soil enzymes was demonstrated by principal component analysis.
Table 2 The percentage of the observed $\eta^{2}$ variability of the effect of the analyzed factors on soil microorganisms (four-way analysis of variance, ANOVA, at $P<0.05$ )

\begin{tabular}{llll}
\hline Variables & Het & Act & Fun \\
\hline $\mathrm{D}$ & 7.494 & 1.456 & 11.013 \\
$\mathrm{~S}$ & 39.110 & 48.934 & 53.713 \\
$\mathrm{Cs}$ & 3.886 & 1.357 & 5.608 \\
$\mathrm{~T}$ & 3.934 & 6.508 & 2.636 \\
$\mathrm{D} \times \mathrm{S}$ & 0.951 & 0.406 & 5.349 \\
$\mathrm{D} \times \mathrm{Cs}$ & 4.787 & 2.925 & 1.797 \\
$\mathrm{~S} \times \mathrm{Cs}$ & 0.166 & 1.888 & 6.468 \\
$\mathrm{D} \times \mathrm{T}$ & 0.350 & 1.106 & 2.918 \\
$\mathrm{~S} \times \mathrm{T}$ & 17.108 & 9.328 & 1.439 \\
$\mathrm{Cs} \times \mathrm{T}$ & 3.664 & 6.162 & 0.374 \\
$\mathrm{D} \times \mathrm{S} \times \mathrm{Cs}$ & 1.707 & 4.454 & 2.388 \\
$\mathrm{D} \times \mathrm{S} \times \mathrm{T}$ & 2.235 & 4.378 & 0.837 \\
$\mathrm{D} \times \mathrm{Cs} \times \mathrm{T}$ & 2.982 & 3.758 & 1.318 \\
$\mathrm{~S} \times \mathrm{Cs} \times \mathrm{T}$ & 1.182 & 1.121 & 0.492 \\
$\mathrm{D} \times \mathrm{S} \times \mathrm{Cs} \times \mathrm{T}$ & 4.705 & 2.802 & 0.657 \\
$\mathrm{Error}$ & 5.738 & 3.416 & 2.994 \\
\hline
\end{tabular}

Het heterotrophic bacteria, Act actinobacteria, Fun fungi, $D$ dose of fungicide, $S$ type of soil, $C s$ fertilizing substance, $T$ date of analysis

\section{Results and discussion}

\section{Soil microorganisms}

In the current study, the analysis of variance (Table 2) showed that the count of microorganisms was most influenced by the soil type (heterotrophic bacteria in 39\%, actinobacteria in $49 \%$, and fungi in 54\%). Chlorothalonil applied to sandy loam and loamy sand caused changes in the count of soil microorganisms (Table 3 ). The fungicide introduction at doses from 0.166 to $16.60 \mathrm{mg} \mathrm{kg}^{-1}$ in loamy sand stimulated the growth of heterotrophic bacteria and actinobacteria both on day 19 and 50 of the experiment. On day 19 of the experiment, chlorothalonil caused an increase in the count of heterotrophic bacteria, which ranged from $27 \%\left(16.60 \mathrm{mg} \mathrm{kg}^{-1}\right)$ to $98 \%\left(0.166 \mathrm{mg} \mathrm{kg}^{-1}\right)$, whereas on day 50 of the experiment-an increase in heterotrophs count from $22 \%\left(0.166 \mathrm{mg} \mathrm{kg}^{-1}\right)$ to $47 \%\left(16.60 \mathrm{mg} \mathrm{kg}^{-1}\right)$. The count of actinobacteria in the pots exposed to the tested fungicide increased from $27 \%\left(0.166 \mathrm{mg} \mathrm{kg}^{-1}\right)$ to $43 \%$ $\left(16.60 \mathrm{mg} \mathrm{kg}^{-1}\right)$ on day 19 as well as from $10 \%(0.166 \mathrm{mg}$ $\left.\mathrm{kg}^{-1}\right)$ to $64 \%$ (16.60 $\left.\mathrm{mg} \mathrm{kg}^{-1}\right)$ on day 50 of the experiment, compared to the control. In the case of fungi, a significant decrease in their count was observed with respect to the control sample. However, the greatest changes were caused by fungicide dose of $16.60 \mathrm{mg} \mathrm{kg}^{-1}$ (fungi count decreased by $76 \%$ on day 19 and by $35 \%$ on day 50 ). In sandy loam, the count of heterotrophic bacteria increased at both experimental time points of measurements. A slight 
Table 3 The count of soil microorganisms, $10^{\mathrm{n}} \mathrm{cfu} \mathrm{kg}^{-1} \mathrm{DM}$ of soil

\begin{tabular}{|c|c|c|c|c|c|c|c|c|c|c|c|c|}
\hline \multirow{4}{*}{$\begin{array}{l}\text { Dose of } \\
\text { fungicide (mg kg } \\
-1 \text { ) }\end{array}$} & \multicolumn{6}{|c|}{ Loamy sand } & \multicolumn{6}{|c|}{ Sandy loam } \\
\hline & \multicolumn{2}{|l|}{ Het $\times 10^{9}$} & \multicolumn{2}{|l|}{ Act $\times 10^{9}$} & \multicolumn{2}{|l|}{ Fun $\times 10^{7}$} & \multicolumn{2}{|l|}{ Het $\times 10^{9}$} & \multicolumn{2}{|c|}{ Act $\times 10^{9}$} & \multicolumn{2}{|l|}{ Fun $\times 10^{7}$} \\
\hline & \multicolumn{12}{|c|}{ Date of analysis (days) } \\
\hline & 19 & 50 & 19 & 50 & 19 & 50 & 19 & 50 & 19 & 50 & 19 & 50 \\
\hline \multicolumn{13}{|c|}{ Soil without fertilizing substance addition } \\
\hline 0.000 & $20.064^{\mathrm{b}}$ & $16.121 \mathrm{~b}$ & $14.638^{\mathrm{d}}$ & $16.247^{\mathrm{cd}}$ & $8.991^{\mathrm{ab}}$ & $6.972^{\mathrm{bc}}$ & $5.951^{\mathrm{d}}$ & $14.892^{\mathrm{bc}}$ & $2.393^{\mathrm{c}}$ & $10.800^{\mathrm{b}}$ & $2.172^{\mathrm{c}}$ & $2.141 \mathrm{c}$ \\
\hline 0.166 & $39.747 a$ & $19.638 b$ & $18.664^{\mathrm{bc}}$ & $17.815^{\mathrm{bcd}}$ & $5.027^{\mathrm{cd}}$ & $9.395^{\mathrm{a}}$ & $10.011^{\mathrm{cd}}$ & $17.962^{\mathrm{ab}}$ & $2.376^{\mathrm{c}}$ & $14.066^{\mathrm{b}}$ & $2.059^{\mathrm{c}}$ & $2.281 \mathrm{c}$ \\
\hline 1.660 & $28.086 \mathrm{ab}$ & $22.782 b$ & $20.241^{\mathrm{b}}$ & $19.017^{\mathrm{bc}}$ & $4.958^{\mathrm{cd}}$ & $5.962^{\mathrm{cd}}$ & $13.687^{\mathrm{bc}}$ & $18.291^{\mathrm{ab}}$ & $2.819^{c}$ & $15.504^{\mathrm{b}}$ & $0.940 \mathrm{~d}$ & $4.700 \mathrm{a}$ \\
\hline 16.60 & $25.439 b$ & $23.658 b$ & $21.001^{\mathrm{b}}$ & $26.720^{\mathrm{a}}$ & $2.125^{\mathrm{e}}$ & $4.500^{\mathrm{d}}$ & $11.771^{\mathrm{c}}$ & $20.170^{\mathrm{a}}$ & $1.654^{\mathrm{c}}$ & $21.919^{\mathrm{a}}$ & $0.509 \mathrm{~d}$ & $3.563 b$ \\
\hline Average & 28.334 & 20.550 & 18.636 & 19.950 & 5.275 & 6.707 & 10.355 & 17.829 & 2.310 & 15.572 & 1.420 & 3.171 \\
\hline$r$ & -0.233 & 0.669 & 0.613 & 0.985 & -0.778 & -0.755 & 0.365 & 0.753 & -0.863 & 0.934 & -0.797 & 0.307 \\
\hline \multicolumn{13}{|l|}{ Lignohumat Super } \\
\hline 0.000 & $34.453 \mathrm{a}$ & $26.779^{\mathrm{ab}}$ & $12.979^{c}$ & $22.295^{\mathrm{ab}}$ & $8.147^{\mathrm{ab}}$ & $5.968^{\mathrm{bc}}$ & $25.322^{\mathrm{a}}$ & $14.339^{\mathrm{b}}$ & $11.332^{\mathrm{bc}}$ & $9.306^{\mathrm{cd}}$ & $2.184 \mathrm{bcd}$ & $3.165 b$ \\
\hline 0.166 & $34.476 a$ & $30.068^{\mathrm{ab}}$ & $14.767^{\mathrm{bc}}$ & $21.693^{\mathrm{ab}}$ & $6.801^{\mathrm{b}}$ & $9.886^{\mathrm{a}}$ & $19.124^{\mathrm{ab}}$ & $17.438^{b}$ & $5.537 \mathrm{de}$ & $12.700^{\mathrm{bc}}$ & $1.591 \mathrm{~cd}$ & $5.314 \mathrm{a}$ \\
\hline 1.660 & $34.794 a$ & $19.613^{\mathrm{b}}$ & $26.465^{\mathrm{a}}$ & $20.556^{\mathrm{abc}}$ & $6.286^{\mathrm{bc}}$ & $5.783^{\mathrm{bc}}$ & $16.765^{b}$ & $16.415^{\mathrm{b}}$ & $5.493 \mathrm{de}$ & $13.907^{\mathrm{b}}$ & $1.588 \mathrm{~cd}$ & $2.604 b c$ \\
\hline 16.60 & $40.890^{\mathrm{a}}$ & $15.681^{\mathrm{b}}$ & $14.230^{\mathrm{bc}}$ & $16.911^{\mathrm{bc}}$ & $6.216^{\mathrm{bc}}$ & $3.660^{c}$ & $15.350^{\mathrm{b}}$ & $15.063^{b}$ & $4.108 \mathrm{e}$ & $22.515^{\mathrm{a}}$ & $0.732 \mathrm{~d}$ & $1.656^{\mathrm{bcd}}$ \\
\hline Average & 36.153 & 23.035 & 17.110 & 20.364 & 6.862 & 6.324 & 19.140 & 15.814 & 6.617 & 14.606 & 1.524 & 3.185 \\
\hline$r$ & 0.999 & -0.800 & -0.216 & -0.977 & -0.543 & -0.712 & -0.630 & -0.336 & -0.565 & 0.959 & -0.905 & -0.696 \\
\hline \multicolumn{13}{|l|}{ Bioilsa N 12.5} \\
\hline 0.000 & $23.680^{\mathrm{cd}}$ & $18.034^{\mathrm{cd}}$ & $23.272^{\mathrm{b}}$ & $22.519^{\mathrm{bc}}$ & $14.929^{\mathrm{a}}$ & $13.424 \mathrm{a}$ & $10.225^{\mathrm{de}}$ & $18.029^{\mathrm{ab}}$ & $6.180 \mathrm{c}$ & $14.270^{\mathrm{a}}$ & $0.796 \mathrm{~d}$ & $3.026 \mathrm{~b}$ \\
\hline 0.166 & $28.575^{\mathrm{bc}}$ & $24.138^{\mathrm{cd}}$ & $23.414^{b}$ & $18.945^{\mathrm{cd}}$ & $10.480^{\mathrm{bc}}$ & $12.746 \mathrm{ab}$ & $15.686^{\mathrm{bc}}$ & $18.518^{\mathrm{ab}}$ & $11.518 b$ & $11.518^{\mathrm{b}}$ & $1.082 \mathrm{~d}$ & $5.441 \mathrm{a}$ \\
\hline 1.660 & $41.665^{\mathrm{a}}$ & $24.540^{\mathrm{bcd}}$ & $23.472^{\mathrm{b}}$ & $18.664^{\mathrm{d}}$ & $7.981^{\mathrm{cd}}$ & $8.044 \mathrm{~cd}$ & $12.726^{\mathrm{cd}}$ & $20.184^{\mathrm{a}}$ & $9.616 \mathrm{~b}$ & $10.822 b$ & $1.269 \mathrm{~cd}$ & $3.047 \mathrm{~b}$ \\
\hline 16.60 & $35.428^{\mathrm{ab}}$ & $15.107^{\mathrm{d}}$ & $34.701^{\mathrm{a}}$ & $17.350^{\mathrm{d}}$ & $6.510^{\mathrm{d}}$ & $5.752 \mathrm{~d}$ & $8.034^{\mathrm{e}}$ & $19.480^{\mathrm{ab}}$ & $2.837 \mathrm{~d}$ & $10.043 b$ & $0.287 \mathrm{~d}$ & $2.518^{b c}$ \\
\hline Average & 32.337 & 20.455 & 26.215 & 19.370 & 9.975 & 9.991 & 11.668 & 19.053 & 7.538 & 11.663 & 0.859 & 3.508 \\
\hline$r$ & 0.349 & -0.727 & 0.997 & -0.652 & -0.684 & -0.820 & -0.730 & 0.382 & -0.800 & -0.639 & -0.851 & -0.534 \\
\hline
\end{tabular}

Het heterotrophic bacteria, Act actinobacteria, Fun fungi, $r$ Pearson's linear correlation coefficient Homogeneous groups were marked with the same letters separately for each group of microorganisms, the type of the soil and the type of fertilizing substance

differences was observed in actinobacteria and fungi response to the test preparation. It was recorded that on day 19 , the count of actinobacteria and fungi decreased compared to the control soil (Table 3). After 50 days since chlorothalonil application in doses ranging from 0.166 to $16.60 \mathrm{mg} \mathrm{kg}^{-1}$, its stimulating effect was observed on counts of actinobacteria and fungi. Considering the mean values, the abundance of heterotrophic bacteria at the highest fungicide dose $\left(16.60 \mathrm{mg} \mathrm{kg}^{-1}\right)$ increased by $36 \%$ in loamy sand and by $53 \%$ in the sandy loam, compared to the control sample. Regarding actinobacteria, the same dose increased the abundance of these microorganisms by $54 \%$ and $79 \%$, respectively. In loamy sand, a reduction in the count of fungi was noted with an increase in the fungicide dose. In sandy loam, a fungicide dose of $1.660 \mathrm{mg} \mathrm{kg}^{-1}$ increased the count of fungi by $30.7 \%$ compared to the soil without fungicide addition. Other doses did not significantly affect fungal growth. Considering that the soil environment is characterized by a vast species diversity of microorganisms (including fungi), it is likely that the soil could be colonized by fungi resistant to chlorothalonil. Intensive farming methods, based on chemical plant protection, can contribute to fungicide penetration to the soil. These substances present in the soil environment pose a potential threat to non-target organisms, including microorganisms. Soil-dwelling microorganisms play significant functions in the nutrient cycling as well as in soil-forming processes. They also enhance plants growth by secreting, among others, enzymes, hormones, and siderophores facilitating iron binding. They can also participate in biological protection of plants against pathogens. Changes in the soil environment caused by the presence of fungicides usually lead to a reduction in the abundance and diversity of microorganisms. The impact of these preparations on soil-dwelling microorganisms depends primarily on the chemical structure of the fungicide itself and its dose, as well as the soil type (Handsa et al. 2014). Hence, organic matter plays a significant functions in protecting the soil environment against chemical contamination. Its high content in the soil affects the sorption properties. In addition, organic matter is capable to adsorb contaminants, including pesticides, which accelerates their degradation (Banach-Szott et al. 2014). 


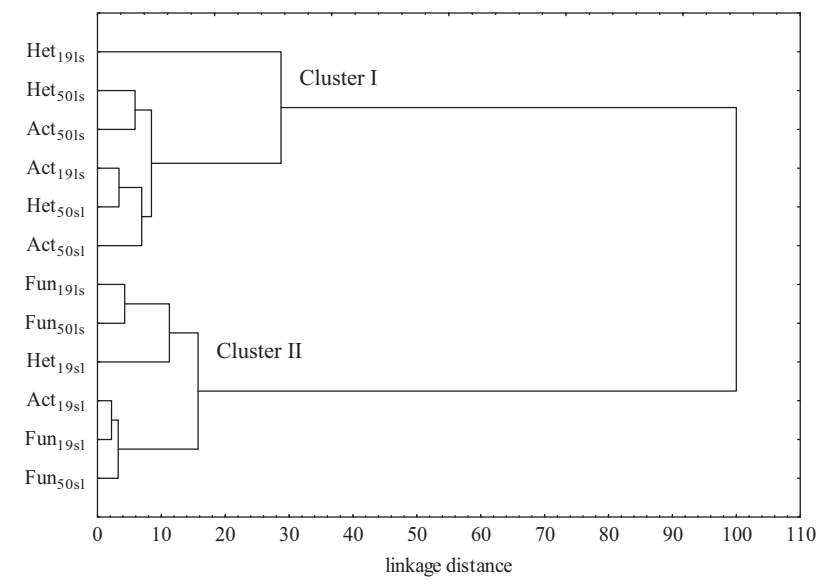

Fig. 1 Similarity of microorganisms response to chlorothalonil soil contamination. Microorganisms: Het heterotrophic bacteria, Act actinobacteria, Fun fungi; type of soil: ls loamy sand, sl sandy loam; date of analysis: $19-19$ days, 50-50 days

Organic compounds are sources of $\mathrm{C}, \mathrm{N}$, and $\mathrm{P}$. They are used by microorganisms as nutrients and energy sources. Soils rich in organic matter also have a higher biological activity (Wang et al. 2009). The cluster analysis (CA) shown in Fig. 1 also indicated the various response of soil microorganisms to chlorothalonil. The first cluster was formed by heterotrophic bacteria and actinobacteria isolated from loamy sand and sandy loam on day 50, and heterotrophic bacteria and actinobacteria from loamy sand on day 19. Counts of these groups of microorganisms were observed to increase along with an increasing dose of chlorothalonil added to the soil. Of all the microorganisms present within this cluster, heterotrophic bacteria isolated from sandy loam on day 50 and actinobacteria isolated from loamy sand on day 19 showed the most similar response to chlorothalonil. The second cluster consisted of heterotrophic bacteria and actinobacteria isolated from sandy loam on day 19 and fungi isolated from loamy sand and sandy loam on days 19 and 50 of the experiment. Based on the clusters formed, it can be stated that actinobacteria and heterotrophic bacteria reacted similarly to the fungicide introduced to the soil. These microorganisms responded to fungicide presence in the soil with their populations increase. It should be noted that the greatest similarity of microorganism response to chlorothalonil action was found between fungi and actinobacteria in sandy loam on day 19 . Many studies (García-Gil et al. 2013; Mohiuddin and Mohammed 2013) indicated that fungicides may lead to the destabilization of soil ecosystems by decreasing the abundance of microorganisms. Studies by Yu et al. (2006) on chlorothalonil have shown that, when introduced into the soil, this substance can have a negative effect on the population of bacteria, fungi, and actinobacteria. The response of soil microorganisms to the applied fungicide
Amistar 250 SC (a.s. azoxystrobin) was also negative in the study conducted by Baćmaga et al. (2015). The toxic effects of benomyl, carbendazim, carboxin, captan, cyclohexamide, fenpropimorph, propiconazole, and triam fungicides on the bacterial population were observed by Milenkovski et al. (2010). In turn, Guo et al. (2015) demonstrated an inhibiting effect of azoxystrobin on the proliferation of bacteria, actinobacteria and fungi, and these changes were dependent on the dose and the retention of the substance in the soil. These authors noted that azoxystrobin applied at doses from 0.1 to $10 \mathrm{mg} \mathrm{kg}^{-1}$ caused the greatest changes in the microbial population after 7 days of soil incubation, i.e., on days 14, 21, and 28. In our study, the introduction of soil fertilizing substances also affected microbiological properties of the soil, thereby contributing to changes in the counts of the analyzed soil microorganisms (Table 3). The average results indicated that the application of Lignohumat Super and Bioilsa N 12.5 to the soil caused an increase in the count of heterotrophic bacteria in both loamy sand and sandy loam, however, a larger impact was observed after the addition of Lignohumat Super. This substance contains as much as $90 \%$ humic acids, which are the source of nutrients, vitamins, and micronutrients. In addition, humic acids also improve soil structure and prevent loss of water and nutrients (Arjumend et al. 2015). Therefore, an increase in the count of microorganisms in the soil could be due to humic acids present in the preparation, which ensured favorable conditions for their development (Hale and Fawy 2011). The application of Bioilsa N 12.5 stimulated the growth of actinobacteria in both loamy sand and sandy loam. The tested fertilizing substances contributed also to an increased count of fungi. Taking into account the term of analysis, it was observed that after Lignohumat Super had been introduced to both loamy sand and sandy loam, the average count of heterotrophic bacteria was the highest on day 19, whereas that of actinobacteria and fungi on day 50 . The effect of Bioilsa N 12.5 on microorganisms counts was slightly different over time, i.e. in loamy sand the microorganisms were more abundant on day 19, while in sandy loam on day 50. The similarity of microorganisms responses to fertilizing substance addition to the soil is shown in Fig. 2. Two groups of microbial responses to the fertilizing substances were identified based on the created dendrogram. Two subgroups were distinguished in the first group, while three subgroups were identified in the second group. The microbial response was determined not only by the type of fertilizing substance, but also by the soil type. However, the highest similarity in response to the fertilizing substances was found in sandy loam.

Fungicide penetration to the soil can also lead to changes in the structure and diversity of soil microbial communities (Imfeld and Vuilleumier 2012). Biodiversity of soil microorganisms is very important, in terms of sustaining the 


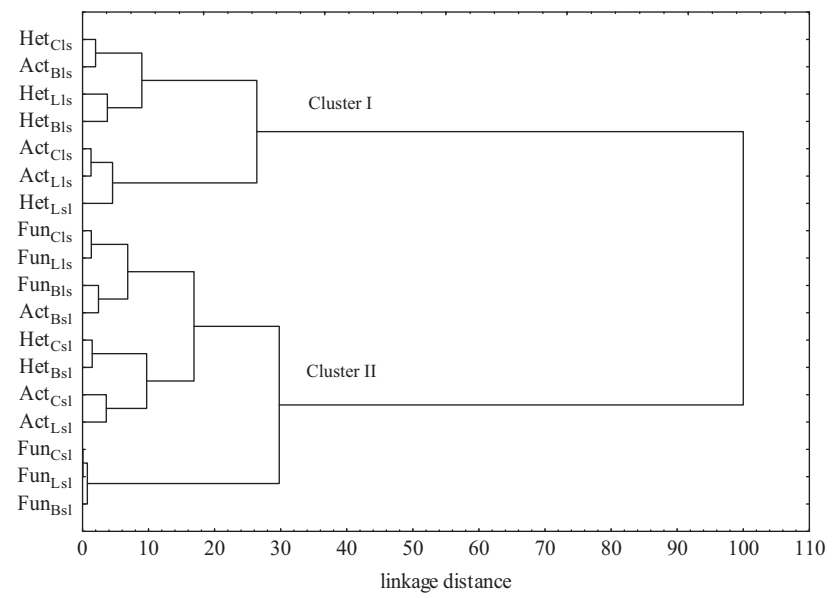

Fig. 2 Similarity of microorganisms response to fertilizing substance. Microorganisms: Het heterotrophic bacteria, Act actinobacteria, Fun fungi; type of soil: ls loamy sand, sl sandy loam; fertilizing substance: $\mathrm{C}$ soil without fertilizing substance addition, $\mathrm{L}$ soil with the addition of Lignohumat Super, B soil with the addition of Bioilsa N 12.5 proper soil health, and therefore, improved crop yields. Disturbance of the activity of soil microorganisms may affect the nutritive soil properties (Janvier et al. 2007). In the current study, the emergence rate of microorganism colonies was largely dependent on soil contamination with chlorothalonil (Tables 4, 5). The average results from the two experimental time points indicated that the highest count of fungi and heterotrophic bacteria was found in the first three days of microbial culture in both loamy sand and sandy loam, which were not exposed to chlorothalonil. This indicated the presence of rapidly growing microorganisms that exhibited adaptive capacity under unfavorable environmental conditions and developed fungicide resistance mechanisms. As a result, microorganisms were able to degrade fungicides by using them as a source of nutrients (Shahgholi 2014). The colonies count of actinobacteria was recorded after 6 days (loamy sand $-42 \%$ and sandy loam$41 \%$ ). The count of colonies of heterotrophic bacteria in loamy sand contaminated with chlorothalonil varied from 8 to $68 \%$, that of actinobacteria from 27 to $40 \%$, and that of

Table 4 The average count of microorganism colonies (\%) growing at particular time intervals $\left(\mathrm{K}_{\mathrm{s}}\right)$ in loamy sand at the two time points

\begin{tabular}{|c|c|c|c|c|c|c|c|c|c|}
\hline \multirow[t]{3}{*}{ Dose of fungicide $\left(\mathrm{mg} \mathrm{kg}^{-1}\right)$} & \multicolumn{3}{|l|}{ Het } & \multicolumn{3}{|l|}{ Act } & \multicolumn{3}{|l|}{ Fun } \\
\hline & \multicolumn{9}{|c|}{ Days of culture } \\
\hline & 3 day & 6 day & 9 day & 3 day & 6 day & 9 day & 3 day & 6 day & 9 day \\
\hline \multicolumn{10}{|c|}{ Soil without fertilizing substance addition } \\
\hline 0.000 & $54.592 b$ & $34.781 \mathrm{c}$ & $10.627 \mathrm{e}$ & $30.354 \mathrm{~cd}$ & $41.824 \mathrm{a}$ & $27.822 \mathrm{c}$ & $83.136 \mathrm{ab}$ & $12.145 \mathrm{e}$ & $4.718 \mathrm{f}$ \\
\hline 0.166 & $65.750 \mathrm{a}$ & $25.505 \mathrm{~cd}$ & $8.745 \mathrm{e}$ & $33.112 \mathrm{bcd}$ & $40.239 \mathrm{ab}$ & $26.649 \mathrm{c}$ & $85.145 \mathrm{a}$ & $10.399 \mathrm{e}$ & $4.457 \mathrm{f}$ \\
\hline 1.660 & $68.117 \mathrm{a}$ & $23.310 \mathrm{~d}$ & $8.573 \mathrm{e}$ & $33.483 \mathrm{c}$ & $39.836 \mathrm{ab}$ & $26.681 \mathrm{c}$ & $80.291 b$ & $11.722 \mathrm{e}$ & $7.987 \mathrm{ef}$ \\
\hline 16.60 & $67.718 \mathrm{a}$ & $24.692 \mathrm{~cd}$ & $7.590 \mathrm{e}$ & 27.177 & $36.398 \mathrm{abc}$ & $36.424 \mathrm{abc}$ & $70.841 \mathrm{c}$ & $17.030 \mathrm{~d}$ & $12.128 \mathrm{e}$ \\
\hline Average & 64.044 & 27.072 & 8.884 & 31.031 & 39.574 & 29.394 & 79.854 & 12.824 & 7.323 \\
\hline$r$ & 0.442 & -0.366 & -0.720 & -0.846 & -0.948 & 0.983 & -0.971 & 0.967 & 0.931 \\
\hline \multicolumn{10}{|l|}{ Lignohumat Super } \\
\hline 0.000 & $64.921 \mathrm{a}$ & $27.753 b$ & $7.326 \mathrm{c}$ & $28.663 \mathrm{fg}$ & $35.427 \mathrm{cde}$ & $35.910 \mathrm{bcde}$ & $71.748 \mathrm{ab}$ & $17.853 \mathrm{de}$ & $10.399 \mathrm{ef}$ \\
\hline 0.166 & $63.059 \mathrm{a}$ & $27.018 b$ & $9.923 \mathrm{c}$ & $23.649 \mathrm{gh}$ & $35.574 \mathrm{bcde}$ & $40.777 \mathrm{ab}$ & $62.371 b c$ & $19.081 \mathrm{de}$ & $18.549 \mathrm{de}$ \\
\hline 1.660 & $66.981 \mathrm{a}$ & $23.182 b$ & $9.837 \mathrm{c}$ & $20.840 \mathrm{~h}$ & $37.887 \mathrm{abc}$ & $41.273 \mathrm{a}$ & $60.888 \mathrm{c}$ & $21.189 \mathrm{~d}$ & $17.923 \mathrm{de}$ \\
\hline 16.60 & $64.964 a$ & $23.940 \mathrm{~b}$ & $11.096 \mathrm{c}$ & $32.515 \mathrm{def}$ & $36.591 \mathrm{abcd}$ & $30.895 \mathrm{ef}$ & $78.778 \mathrm{a}$ & $15.092 \mathrm{def}$ & $6.129 f$ \\
\hline Average & 64.981 & 25.473 & $9.545 \mathrm{c}$ & 26.417 & 36.370 & 37.214 & 68.446 & 18.304 & 13.250 \\
\hline$r$ & 0.070 & -0.535 & 0.687 & 0.731 & 0.221 & -0.834 & 0.781 & -0.789 & -0.755 \\
\hline \multicolumn{10}{|l|}{ Bioilsa N 12.5} \\
\hline 0.000 & $66.036 \mathrm{a}$ & $23.135 b$ & $10.829 \mathrm{c}$ & $36.468 \mathrm{bc}$ & $34.455 \mathrm{~cd}$ & $29.077 \mathrm{de}$ & $80.494 a$ & $14.972 \mathrm{~b}$ & $4.534 \mathrm{c}$ \\
\hline 0.166 & $65.394 \mathrm{a}$ & $23.754 b$ & $10.851 \mathrm{c}$ & $41.345 \mathrm{ab}$ & $36.543 \mathrm{bc}$ & $22.112 \mathrm{f}$ & $78.038 \mathrm{a}$ & $17.564 b$ & $4.397 \mathrm{c}$ \\
\hline 1.660 & $64.069 \mathrm{a}$ & $25.450 \mathrm{~b}$ & $10.482 \mathrm{c}$ & $44.647 \mathrm{a}$ & $33.946 \mathrm{cde}$ & $21.407 \mathrm{f}$ & $79.336 a$ & $17.005 \mathrm{~b}$ & $3.659 \mathrm{c}$ \\
\hline 16.60 & $69.764 a$ & $23.010 \mathrm{~b}$ & $7.226 \mathrm{c}$ & $34.081 \mathrm{cde}$ & $38.387 \mathrm{abc}$ & $27.532 \mathrm{ef}$ & $78.060 \mathrm{a}$ & $18.792 \mathrm{~b}$ & $3.148 \mathrm{c}$ \\
\hline Average & 66.316 & 23.837 & 9.847 & 39.135 & 35.833 & 25.032 & 78.982 & 17.083 & 3.935 \\
\hline$r$ & 0.908 & -0.409 & -1.000 & -0.649 & 0.801 & 0.378 & -0.525 & 0.738 & -0.858 \\
\hline
\end{tabular}

Het heterotrophic bacteria, Act actinobacteria, Fun fungi, $r$ Pearson's linear correlation coefficient Homogeneous groups were marked with the same letters separately for each group of microorganisms and the type of fertilizing substance 
Table 5 The average count of microorganism colonies $(\%)$ growing at particular time intervals $\left(\mathrm{K}_{\mathrm{s}}\right)$ in sandy loam at the two time points

\begin{tabular}{|c|c|c|c|c|c|c|c|c|c|}
\hline \multirow[t]{3}{*}{ Dose of fungicide $\left(\mathrm{mg} \mathrm{kg}^{-1}\right)$} & \multicolumn{3}{|l|}{ Het } & \multicolumn{3}{|l|}{ Act } & \multicolumn{3}{|l|}{ Fun } \\
\hline & \multicolumn{9}{|c|}{ Days of culture } \\
\hline & 3 day & 6 day & 9 day & 3 day & 6 day & 9 day & 3 day & 6 day & 9 day \\
\hline \multicolumn{10}{|c|}{ Soil without fertilizing substance addition } \\
\hline 0.000 & $72.330 \mathrm{a}$ & $21.150 \mathrm{~b}$ & $6.520 \mathrm{~cd}$ & $30.655 \mathrm{bcde}$ & $40.813 \mathrm{a}$ & $28.532 \mathrm{cde}$ & $81.271 \mathrm{a}$ & $17.734 \mathrm{~cd}$ & $0.995 \mathrm{e}$ \\
\hline 0.166 & $63.875 \mathrm{a}$ & $28.946 b$ & $7.179 \mathrm{~cd}$ & $26.412 \mathrm{de}$ & 34.819abcd & $38.769 \mathrm{ab}$ & $74.044 \mathrm{a}$ & $18.019 \mathrm{~cd}$ & $7.937 \mathrm{~d}$ \\
\hline 1.660 & $65.620 \mathrm{a}$ & $27.755 b$ & $6.621 \mathrm{~cd}$ & $26.497 \mathrm{de}$ & 34.942abcd & $38.561 \mathrm{abc}$ & $60.885 b$ & $27.745 c$ & $11.370 \mathrm{~d}$ \\
\hline 16.60 & $75.697 \mathrm{a}$ & $19.471 \mathrm{bc}$ & $4.832 \mathrm{c}$ & 39.992ab & $37.261 \mathrm{abc}$ & $22.747 \mathrm{e}$ & $82.702 \mathrm{a}$ & $15.138 \mathrm{~d}$ & $2.160 \mathrm{e}$ \\
\hline Average & 69.381 & 24.331 & 6.288 & 30.889 & 36.959 & 32.152 & 74.725 & 19.659 & 5.616 \\
\hline$r$ & 0.728 & -0.653 & -0.962 & 0.930 & 0.019 & -0.760 & 0.455 & -0.463 & -0.402 \\
\hline \multicolumn{10}{|l|}{ Lignohumat Super } \\
\hline 0.000 & $71.735 \mathrm{ab}$ & $20.428 \mathrm{~cd}$ & $7.837 \mathrm{fg}$ & $38.028 \mathrm{ab}$ & $39.191 \mathrm{ab}$ & $22.781 \mathrm{~cd}$ & $87.119 a$ & $11.086 \mathrm{~b}$ & $1.795 \mathrm{c}$ \\
\hline 0.166 & $73.427 \mathrm{ab}$ & $18.075 \mathrm{cde}$ & $8.498 \mathrm{efg}$ & $40.254 \mathrm{ab}$ & $39.518 \mathrm{ab}$ & $20.228 d$ & $90.497 \mathrm{a}$ & $5.075 b c$ & $4.428 \mathrm{bc}$ \\
\hline 1.660 & $77.637 \mathrm{a}$ & $16.307 \mathrm{def}$ & $6.056 \mathrm{~g}$ & $41.547 \mathrm{a}$ & $37.469 \mathrm{ab}$ & $20.984 \mathrm{~cd}$ & $89.057 \mathrm{a}$ & $5.652 \mathrm{bc}$ & $5.291 \mathrm{bc}$ \\
\hline 16.60 & $67.782 \mathrm{~b}$ & $27.050 \mathrm{c}$ & $5.167 \mathrm{~g}$ & $35.247 \mathrm{~b}$ & $38.385 \mathrm{ab}$ & $26.368 \mathrm{c}$ & $88.549 a$ & $6.272 \mathrm{bc}$ & $5.179 \mathrm{bc}$ \\
\hline Average & 72.645 & 20.465 & 6.890 & 38.769 & 38.641 & 22.590 & 88.806 & 7.021 & 4.173 \\
\hline$r$ & -0.735 & 0.900 & -0.799 & -0.806 & -0.274 & 0.905 & -0.106 & -0.227 & 0.473 \\
\hline \multicolumn{10}{|l|}{ Bioilsa N 12.5} \\
\hline 0.000 & $62.728 \mathrm{a}$ & $30.244 c$ & $7.029 \mathrm{~d}$ & $36.801 \mathrm{a}$ & $35.553 \mathrm{a}$ & $27.646 b$ & $75.803 \mathrm{a}$ & $16.689 \mathrm{~cd}$ & $7.509 \mathrm{~d}$ \\
\hline 0.166 & $57.628 \mathrm{ab}$ & $32.977 \mathrm{c}$ & $9.395 \mathrm{~d}$ & $35.932 \mathrm{a}$ & $29.277 b$ & $34.790 \mathrm{a}$ & $54.171 \mathrm{ab}$ & $35.818 \mathrm{c}$ & $10.011 \mathrm{~d}$ \\
\hline 1.660 & $55.121 \mathrm{ab}$ & $34.603 \mathrm{c}$ & $10.276 \mathrm{~d}$ & $35.154 \mathrm{a}$ & $30.822 b$ & $34.024 \mathrm{a}$ & $64.208 \mathrm{ab}$ & $26.744 \mathrm{c}$ & $9.049 \mathrm{~d}$ \\
\hline 16.60 & $51.562 \mathrm{~b}$ & $34.669 d$ & $13.769 d$ & $28.356 \mathrm{~b}$ & $37.843 \mathrm{a}$ & $33.801 \mathrm{a}$ & $70.244 a$ & $17.162 \mathrm{~cd}$ & $12.594 \mathrm{~cd}$ \\
\hline Average & 56.760 & 33.123 & 10.117 & 34.061 & 33.374 & 32.565 & 66.106 & 24.103 & 9.791 \\
\hline$r$ & -0.786 & 0.563 & 0.903 & -0.995 & 0.719 & 0.293 & 0.285 & -0.498 & 0.882 \\
\hline
\end{tabular}

Het heterotrophic bacteria, Act actinobacteria, Fun fungi, $r$ Pearson's linear correlation coefficient Homogeneous groups were marked with the same letters separately for each group of microorganisms soil and the type of fertilizing substance

fungi from 4 to $85 \%$. In sandy loam, heterotrophic bacteria developed in the range from 5 to $76 \%$, actinobacteria from 23 to $40 \%$ and fungi from 10 to $83 \%$. Changes in the structure of microorganisms under the influence of triadimefon and propiconazole introduced into the soil at doses of 10 and $100 \mathrm{mg} \mathrm{kg}^{-1}$ were recorded by Yen et al. (2009). In turn, Wang et al. (2009) demonstrated that the repeated application of carbendazim (at doses from 0.94 to $4.70 \mathrm{~kg}$ a. $\mathrm{i} \mathrm{ha}^{-1}$ ) could reduce the diversity of the bacterial population and alter the structure of their community. Most colonies of heterotrophic bacteria and fungi in the soil supplemented with Lignohumat Super grew after 3 days of the culture. In this period, on average $65 \%$ of colonies of heterotrophic bacteria and $68 \%$ of fungi grew in loamy sand as well as $73 \%$ of colonies of heterotrophic bacteria and $89 \%$ of fungi in sandy loam. In the objects with Biolilsa N 12.5 addition, colonies of all analyzed microorganisms groups grew fastest on day 3 of the culture (heterotrophic bacteria amounted on average to $66 \%$, actinobacteria-39\% and fungi-79\%). In sandy loam, the highest count of grown colonies of heterotrophic bacteria and fungi was recorded on day 3 of the culture (57\% and 66\%, respectively).

\section{Soil enzymes}

Statistical analysis showed that the factors tested contributed to changes in the soil enzymes activity. Chlorothalonil dose affected mostly the activity of urease. Soil type had a stronger effect on the activities of acid phosphatase and alkaline phosphatase, whereas date of analysis - on the activities of dehydrogenase and catalase (Table 6). Any contaminant entering the soil can interfere with biogeochemical processes. Some fungicides can inhibit, but also stimulate the soil microbial activity. Disturbances in soil microbial activity indirectly affect the enzymatic activity of the soil ecosystem (Stefani et al. 2012). Suppression of the enzymatic activity of soil may be due to increased mortality of microorganisms triggered by toxic doses of pesticides. As a result of this, physiological processes of microorganisms are rejected. This in turn leads to modification of the course of enzymes activity, which are mainly secreted by microorganisms. By taking part in many processes proceeding in soil and in biogeochemical circulations, soil enzymes are reliable indicators of changes occurring in soil that may be potentially used to evaluate soil quality and fertility (Bielińska and Pranagal 2007; Kızılkaya 
Table 6 The percentage of the observed $\eta^{2}$ variability of the effect of the analyzed factors on soil enzymatic activity (four-way analysis of variance, ANOVA, at $P<0.05$ )

\begin{tabular}{llllll}
\hline Variables & Deh & Cat & Ure & Pac & Pal \\
\hline $\mathrm{D}$ & 4.732 & 19.738 & 21.034 & 3.812 & 4.236 \\
$\mathrm{~S}$ & 1.055 & 16.687 & 1.710 & 52.781 & 72.692 \\
$\mathrm{Cs}$ & 1.093 & 5.033 & 2.307 & 2.124 & 0.675 \\
$\mathrm{~T}$ & 79.665 & 36.758 & 5.988 & 9.152 & 11.201 \\
$\mathrm{D} \times \mathrm{S}$ & 0.016 & 0.073 & 4.850 & 2.139 & 0.702 \\
$\mathrm{D} \times \mathrm{Cs}$ & 0.786 & 6.297 & 9.841 & 2.625 & 0.412 \\
$\mathrm{~S} \times \mathrm{Cs}$ & 2.855 & 0.128 & 0.893 & 5.962 & 0.406 \\
$\mathrm{D} \times \mathrm{T}$ & 1.232 & 0.789 & 1.636 & 3.940 & 0.355 \\
$\mathrm{~S} \times \mathrm{T}$ & 3.824 & 2.526 & 18.319 & 0.111 & 0.863 \\
$\mathrm{Cs} \times \mathrm{T}$ & 1.494 & 1.553 & 5.357 & 0.417 & 1.468 \\
$\mathrm{D} \times \mathrm{S} \times \mathrm{Cs}$ & 0.251 & 2.299 & 6.685 & 4.769 & 0.298 \\
$\mathrm{D} \times \mathrm{S} \times \mathrm{T}$ & 0.181 & 0.281 & 0.273 & 1.317 & 0.540 \\
$\mathrm{D} \times \mathrm{Cs} \times \mathrm{T}$ & 0.518 & 3.500 & 9.767 & 4.408 & 0.443 \\
$\mathrm{~S} \times \mathrm{Cs} \times \mathrm{T}$ & 1.589 & 0.359 & 1.798 & 2.758 & 0.684 \\
$\mathrm{D} \times \mathrm{S} \times \mathrm{Cs} \times \mathrm{T}$ & 0.297 & 1.683 & 5.271 & 1.265 & 0.045 \\
$\mathrm{Error}$ & 0.412 & 2.296 & 4.270 & 2.422 & 4.980 \\
\hline
\end{tabular}

Deh dehydrogenases, Cat catalase, Ure urease, Pac acid phosphatase, $\mathrm{Pal}$ alkaline phosphatase, $D$ dose of fungicide, $S$ type of soil, $C s$ fertilizing substance, $T$ date of analysis

et al. 2012; Ye et al. 2018). In line with this, results obtained in our study enable concluding that the analyzed factors exerted various effects on the biochemical properties of loamy sand (Table 7) and sandy loam (Table 8). Chlorothalonil addition to the soil in the highest dose $\left(16.60 \mathrm{mg} \mathrm{kg}^{-1}\right)$ had an inhibiting effect on activities of dehydrogenases, catalase, and acid phosphate in both soil types. In loamy sand, this dose of chlorothalonil suppressed the activity of dehydrogenases by $47 \%$, that of catalase by $34 \%$, and that of acid phosphatase by $17 \%$ on average, whereas in sandy loam-by $35 \%, 20 \%$, and $34 \%$ in the case of dehydrogenases, catalase, and acid phosphatase, respectively. The response of the other enzymes to chlorothalonil was not that explicit and depended to a greater extent on soil type and date of analysis. The PCA analysis presented in Fig. 3 also confirmed the significant impact of the examined factors. The activity of soil enzymes in loamy sand was affected by the first principal component in $60 \%$ and by the second in $26 \%$. Similar correlations were observed in sandy loam, where the first principal component explained $61.37 \%$ of the total variables variance, while the second $25 \%$. The activity of soil enzymes was altered by the excessive amounts of chlorothalonil. Both in loamy sand and sandy loam (day 19 and 50), this fungicide inhibited the activity of acid phosphatase, catalase and dehydrogenases. The highest dose caused the greatest changes $\left(16.60 \mathrm{mg} \mathrm{kg}^{-1}\right)$. Chlorothalonil exerted variable effects on urease and alkaline phosphatase activities. This was primarily dependent on the type of the soil and the time point of analysis. Wu et al.
(2012) observed that multiple applications of chlorothalonil at $10 \mathrm{mg}$ and $25 \mathrm{mg} \mathrm{kg}^{-1}$ increased the stability of this substance, and thus led to changes in soil enzymatic activity. Sopeña and Bending (2013) tested three fungicides (azoxystrobin, chlorothalonil, tebuconazole) and reported lower dehydrogenase activity. The negative impact of Falcon 460 EC fungicide on soil enzymes (acid phosphatase, alkaline phosphatase, catalase, urease) was also reported in our previous study (Baćmaga et al. 2016), especially upon the use of the highest fungicide dose $\left(27.6 \mathrm{mg} \mathrm{kg}^{-1}\right)$. Tebuconazole used at 5,50 and $500 \mathrm{mg} \mathrm{kg}^{-1}$ also reduced the activity of alkaline phosphatase, arylsulfatase, $\beta$-glucosidase and urease in the soil tested by Muñoz-Leoz et al. (2011). Saha et al. (2016) also investigated the effect of tebuconazole on soil enzymatic activity. They observed short-term and transient toxic effects of tebuconazole applied at three doses (dose recommended, twofold and tenfold higher doses than recommended) on the activity of arylsulfatase, fluorescein diacetate, phosphatase, and urease. However, the activity of dehydrogenases and nitrate reductase drastically decreased after application of this fungicide. A reduction in the activity of phosphatases, amylase, and invertase (a dose from 10 to $2000 \mathrm{mg} \mathrm{kg}^{-1}$ ) caused by mancozeb was reported by Walia et al. (2014). It should be emphasized that the negative impact of fungicides on the microbiological and biochemical properties of soil ecosystems is generally recorded in soils where these substances are applied at doses many times higher than those recommended by the manufacturer. Some preparations introduced into the soil in excess contribute to the stimulation of enzyme activity. Increases in dehydrogenase, arylamidase, and myrosinase activities were reported in response to the application of mancozeb and carbendazim (Srinivasulu and Rangaswamy 2013) fungicides to the soil. Prochlorazole also acted as an activating agent on dehydrogenase, urease, phosphatase, and $\beta$-glucosidase (Tejada et al. 2011).

The negative impact of fungicides on soil enzyme activities can be neutralized by adding attenuating substances to the soil, such as compost, manure, basalt meal, or bentonite. Their application to the soil can lead to the stimulation of naturally occurring microorganisms in this environment, thereby, accelerating the rate of fungicide degradation (Adams et al. 2015). In our study, soil supplementation with fertilizing substances had a varied effect on the soil enzymes activity. Their impact was primarily dependent on the type of the soil and enzyme tested (Tables 7, 8, Fig. 3). In loamy sand, Lignohumat Super and Bioilsa $\mathrm{N} 12.5$ preparations caused an increased activity of all enzymes tested. Lignohumat Super increased the activity of dehydrogenases (irrespective of chlorothalonil dose and analysis date) by $7 \%$, that of catalase by $12 \%$, that of acid phosphatase by $13 \%$, and that of alkaline phosphatase by $6 \%$ on average, compared to the soil with no addition of fertilizing substances. In turn, Bioilsa N 12.5 increased the 
Table 7 Enzymatic activity in loamy sand, $\mathrm{kg}^{-1} \mathrm{DM}$ of soil $\mathrm{h}^{-1}$

\begin{tabular}{|c|c|c|c|c|c|c|c|c|c|c|}
\hline \multirow[t]{3}{*}{ Dose of fungicide $\left(\mathrm{mg} \mathrm{kg}^{-1}\right)$} & \multicolumn{2}{|c|}{$\begin{array}{l}\text { Dehydrogenases } \\
(\mu \mathrm{Mol} \text { TPF) }\end{array}$} & \multicolumn{2}{|c|}{ Catalase $(\mathrm{Mol} \mathrm{O} 2)$} & \multicolumn{2}{|c|}{$\begin{array}{l}\text { Urease (mMol N- } \\
\left.\mathrm{NH}_{4}\right)\end{array}$} & \multicolumn{2}{|c|}{$\begin{array}{l}\text { Acid phosphatase } \\
\text { (mMol PNP) }\end{array}$} & \multicolumn{2}{|c|}{$\begin{array}{l}\text { Alkaline } \\
\text { phosphatase } \\
(\mathrm{mMol} P N P)\end{array}$} \\
\hline & \multicolumn{10}{|c|}{ Date of analysis (days) } \\
\hline & 19 & 50 & 19 & 50 & 19 & 50 & 19 & 50 & 19 & 50 \\
\hline \multicolumn{11}{|c|}{ Soil without fertilizing substance addition } \\
\hline 0.000 & $3.466 \mathrm{c}$ & $10.441 \mathrm{a}$ & $0.232 \mathrm{a}$ & $0.214 \mathrm{a}$ & $0.367 \mathrm{ab}$ & $0.136 \mathrm{~d}$ & $1.405 \mathrm{c}$ & $1.485 \mathrm{bc}$ & $0.701 \mathrm{~d}$ & $0.914 \mathrm{c}$ \\
\hline 0.166 & $2.890 \mathrm{~cd}$ & $10.815 \mathrm{a}$ & $0.225 \mathrm{a}$ & $0.143 \mathrm{c}$ & $0.461 \mathrm{a}$ & $0.330 \mathrm{~b}$ & $1.614 \mathrm{ab}$ & $1.692 \mathrm{a}$ & $0.822 \mathrm{c}$ & $1.123 \mathrm{ab}$ \\
\hline 1.660 & $2.773 \mathrm{~cd}$ & $9.941 \mathrm{a}$ & $0.216 \mathrm{a}$ & $0.117 \mathrm{~d}$ & $0.346 \mathrm{ab}$ & $0.269 \mathrm{bc}$ & $0.890 \mathrm{~d}$ & $1.691 \mathrm{a}$ & $0.668 \mathrm{~d}$ & $1.136 \mathrm{a}$ \\
\hline 16.60 & $1.540 \mathrm{~d}$ & $5.764 b$ & $0.175 b$ & $0.119 \mathrm{~d}$ & $0.344 \mathrm{ab}$ & $0.154 \mathrm{~cd}$ & $0.876 \mathrm{~d}$ & $1.535 \mathrm{abc}$ & $0.602 \mathrm{~d}$ & $1.025 \mathrm{~b}$ \\
\hline Average & 2.667 & 9.240 & 0.212 & 0.148 & 0.380 & 0.222 & 1.196 & 1.601 & 0.698 & 1.050 \\
\hline$r$ & -0.948 & -0.996 & -0.985 & -0.492 & -0.474 & -0.464 & -0.643 & -0.360 & -0.733 & -0.101 \\
\hline \multicolumn{11}{|l|}{ Lignohumat Super } \\
\hline 0.000 & $4.294 d$ & $9.486 \mathrm{~b}$ & $0.253 b$ & $0.182 \mathrm{c}$ & $0.522 \mathrm{ab}$ & $0.331 \mathrm{bc}$ & $1.622 \mathrm{ab}$ & $1.558 \mathrm{ab}$ & $0.852 b$ & $1.067 \mathrm{a}$ \\
\hline 0.166 & 3.810de & $11.05 \mathrm{a}$ & $0.279 \mathrm{a}$ & $0.201 \mathrm{c}$ & $0.578 \mathrm{a}$ & $0.370 \mathrm{~b}$ & $1.630 \mathrm{ab}$ & $1.736 \mathrm{a}$ & $1.194 \mathrm{a}$ & $1.081 \mathrm{a}$ \\
\hline 1.660 & $3.181 \mathrm{ef}$ & $10.84 \mathrm{a}$ & $0.234 b$ & $0.133 \mathrm{~d}$ & $0.423 \mathrm{ab}$ & $0.154 \mathrm{~cd}$ & $1.522 \mathrm{ab}$ & $1.542 \mathrm{ab}$ & $0.686 \mathrm{c}$ & $1.005 \mathrm{a}$ \\
\hline 16.60 & $2.554 \mathrm{f}$ & $5.913 \mathrm{c}$ & $0.198 \mathrm{c}$ & $0.129 \mathrm{~d}$ & $0.367 \mathrm{~b}$ & $0.077 \mathrm{~d}$ & $1.515 b$ & $1.495 \mathrm{~b}$ & $0.574 \mathrm{~d}$ & $0.938 \mathrm{ab}$ \\
\hline Average & 3.460 & 9.322 & 0.241 & 0.161 & 0.473 & 0.233 & 1.572 & 1.583 & 0.827 & 1.023 \\
\hline$r$ & -0.847 & -0.940 & -0.876 & -0.667 & -0.792 & -0.799 & -0.683 & -0.589 & -0.670 & -0.905 \\
\hline \multicolumn{11}{|l|}{ Bioilsa N12.5 } \\
\hline 0.000 & $3.676 \mathrm{c}$ & $12.515 \mathrm{a}$ & $0.237 \mathrm{a}$ & $0.161 \mathrm{c}$ & $0.173 c$ & $0.212 b c$ & $1.366 \mathrm{e}$ & $1.674 \mathrm{bc}$ & $0.950 \mathrm{bc}$ & $1.142 \mathrm{a}$ \\
\hline 0.166 & $3.435 \mathrm{c}$ & $11.900 \mathrm{a}$ & $0.237 \mathrm{a}$ & $0.179 \mathrm{c}$ & $0.443 a$ & $0.307 \mathrm{abc}$ & $1.878 \mathrm{~b}$ & $1.645 \mathrm{c}$ & $0.846 \mathrm{~cd}$ & $1.174 \mathrm{a}$ \\
\hline 1.660 & $2.555 \mathrm{c}$ & $9.697 b$ & $0.225 \mathrm{ab}$ & $0.212 b$ & $0.461 \mathrm{a}$ & $0.328 \mathrm{abc}$ & $1.605 \mathrm{~cd}$ & $2.192 \mathrm{a}$ & $0.773 \mathrm{~d}$ & $1.105 \mathrm{a}$ \\
\hline 16.60 & $2.515 \mathrm{c}$ & $9.627 \mathrm{~b}$ & $0.208 b$ & $0.173 \mathrm{c}$ & $0.348 \mathrm{ab}$ & $0.231 b c$ & $1.390 \mathrm{de}$ & $2.385 \mathrm{a}$ & $0.597 \mathrm{e}$ & $0.964 b$ \\
\hline Average & 3.045 & 10.935 & 0.227 & 0.181 & 0.356 & 0.270 & 1.560 & 1.974 & 0.792 & 1.096 \\
\hline$r$ & -0.663 & -0.657 & -0.945 & -0.164 & 0.016 & -0.393 & -0.469 & 0.796 & -0.908 & -0.972 \\
\hline
\end{tabular}

$r$ Pearson's linear correlation coefficientHomogeneous groups were marked with the same letters separately for each group of enzymes and the type of fertilizing substance

activity of dehydrogenases by $17 \%$, that of catalase by $13 \%$, that of urease by $4 \%$, that of acid phosphate by $26 \%$, and that of alkaline phosphatase by $8 \%$ on average. The highest content of organic matter contained in the tested compounds helped stimulate enzymes secreted by microorganisms and plants, thereby increasing their count. In addition, organic matter is a catalyst for many biological processes occurring in the soil environment, especially in light soils (BanachSzott et al. 2014). The effect of these preparations was slightly different in sandy loam. It was observed that the activity of dehydrogenases and acid phosphatase decreased after application of these fertilizers to the soil. Lignohumat Super decreased the activity of dehydrogenases (irrespective of chlorothalonil dose and analysis date) by $31 \%$ and that of acid phosphatase by $16 \%$, whereas Bioilsa N $12.5-$ by $28 \%$ in the case of dehydrogenases and by $10 \%$ in the case of acid phosphatase. The tested fertilizing substances introduced to sandy loam stimulated activities of catalase and urease. Catalase activity in pots with the addition of Lignohumat Super and Bioilsa N 12.5 preparations increased by ca. $8 \%$ on average, whereas urease activity increased by $11 \%$ on average upon the addition of Lignohumat Super and by $15 \%$ upon the addition of Bioilsa N 12.5. This reduction in enzyme activity could be attributed to the substrate and enzyme adsorption on organic matter surface, resulting in the formation of a substrate-enzyme complex. This in turn caused the inhibition of enzymatic reactions in the soil (Trckova et al. 2004). On day 50 of the experiment, the highest activity was observed for dehydrogenases, acid phosphatase, and alkaline phosphatase both in loamy sand and sandy loam, while on day 19 for catalase activity. Oleszczuk et al. (2014) stated the beneficial impact of biocarbon on the enzymatic activity of the soil treated with dicamba and 2,4-D pesticides.

\section{Chlorothalonil residues in the soil}

Despite being so small in size, soil microorganisms are very active in the degradation of pollutants, including fungicides, entering the soil environment (Murali and Mehar 2014). With their participation, the most stable compounds are usually decomposed into less toxic substances. However, 
Table 8 Enzymatic activity in sandy loam, $\mathrm{kg}^{-1} \mathrm{DM}$ of soil $\mathrm{h}^{-1}$

\begin{tabular}{|c|c|c|c|c|c|c|c|c|c|c|}
\hline \multirow[t]{3}{*}{ Dose of fungicide $\left(\mathrm{mg} \mathrm{kg}^{-1}\right)$} & \multicolumn{2}{|c|}{$\begin{array}{l}\text { Dehydrogenases } \\
(\mu \mathrm{Mol} \text { TPF) }\end{array}$} & \multicolumn{2}{|c|}{ Catalase $(\mathrm{Mol} \mathrm{O})_{2}$} & \multicolumn{2}{|c|}{$\begin{array}{l}\text { Urease (mMol N- } \\
\left.\mathrm{NH}_{4}\right)\end{array}$} & \multicolumn{2}{|c|}{$\begin{array}{l}\text { Acid phosphatase } \\
\text { (mMol PNP) }\end{array}$} & \multicolumn{2}{|c|}{$\begin{array}{l}\text { Alkaline } \\
\text { phosphatase } \\
(\mathrm{mMol} P N P)\end{array}$} \\
\hline & \multicolumn{10}{|c|}{ Date of analysis (days) } \\
\hline & 19 & 50 & 19 & 50 & 19 & 50 & 19 & 50 & 19 & 50 \\
\hline \multicolumn{11}{|c|}{ Soil without fertilizing substance addition } \\
\hline 0.000 & $2.432 \mathrm{de}$ & $18.449 a$ & $0.260 \mathrm{a}$ & $0.229 \mathrm{bcd}$ & $0.385 \mathrm{a}$ & $0.251 b$ & $1.408 \mathrm{a}$ & $1.358 \mathrm{ab}$ & $1.720 \mathrm{e}$ & $2.383 b$ \\
\hline 0.166 & $2.880 \mathrm{~d}$ & $17.720 \mathrm{a}$ & $0.243 \mathrm{ab}$ & $0.214 \mathrm{~d}$ & $0.368 \mathrm{ab}$ & $0.327 \mathrm{ab}$ & $0.888 \mathrm{def}$ & $1.190 \mathrm{bc}$ & $1.485 f$ & $2.494 \mathrm{a}$ \\
\hline 1.660 & $2.850 \mathrm{~d}$ & $16.165 b$ & $0.236 \mathrm{bc}$ & $0.170 \mathrm{e}$ & $0.364 \mathrm{ab}$ & $0.347 \mathrm{ab}$ & $0.851 \mathrm{def}$ & $1.076 \mathrm{~cd}$ & $1.403 \mathrm{fg}$ & $2.248 \mathrm{c}$ \\
\hline 16.60 & $1.410 \mathrm{e}$ & $12.247 \mathrm{c}$ & $0.221 \mathrm{~cd}$ & $0.168 \mathrm{e}$ & $0.253 b$ & $0.308 \mathrm{ab}$ & $0.762 \mathrm{f}$ & $1.063 \mathrm{~cd}$ & $1.328 \mathrm{~g}$ & $2.148 \mathrm{~d}$ \\
\hline Average & 2.393 & 16.145 & 0.240 & 0.195 & 0.343 & 0.308 & 0.977 & 1.172 & 1.484 & 2.318 \\
\hline$r$ & -0.936 & -0.966 & -0.825 & -0.659 & -0.994 & 0.064 & -0.540 & -0.596 & -0.665 & -0.797 \\
\hline \multicolumn{11}{|l|}{ Lignohumat Super } \\
\hline 0.000 & $2.101 \mathrm{e}$ & $13.070 \mathrm{a}$ & $0.273 a$ & $0.211 \mathrm{c}$ & $0.368 \mathrm{ab}$ & $0.462 \mathrm{a}$ & $0.569 \mathrm{c}$ & $1.174 \mathrm{a}$ & $1.941 \mathrm{c}$ & $2.231 \mathrm{a}$ \\
\hline 0.166 & $2.532 \mathrm{e}$ & $11.712 b$ & $0.292 \mathrm{a}$ & $0.234 \mathrm{~b}$ & $0.409 \mathrm{ab}$ & $0.403 \mathrm{ab}$ & $0.902 \mathrm{ab}$ & $1.060 \mathrm{a}$ & $1.727 \mathrm{~d}$ & $2.103 b$ \\
\hline 1.660 & $2.357 \mathrm{e}$ & $10.876 \mathrm{c}$ & $0.246 \mathrm{~b}$ & $0.214 \mathrm{c}$ & $0.427 \mathrm{ab}$ & $0.346 \mathrm{ab}$ & $0.866 \mathrm{abc}$ & $1.040 \mathrm{a}$ & $1.569 \mathrm{e}$ & $1.973 \mathrm{c}$ \\
\hline 16.60 & $1.191 \mathrm{f}$ & $7.110 \mathrm{~d}$ & $0.206 \mathrm{c}$ & $0.198 \mathrm{c}$ & $0.156 \mathrm{c}$ & $0.310 \mathrm{~b}$ & $0.611 b c$ & $1.036 \mathrm{a}$ & $1.372 \mathrm{f}$ & $1.683 \mathrm{de}$ \\
\hline Average & 2.045 & 10.692 & 0.254 & 0.214 & 0.340 & 0.380 & 0.737 & 1.078 & 1.652 & 1.998 \\
\hline$r$ & -0.945 & -0.959 & -0.900 & -0.744 & -0.962 & -0.760 & -0.448 & -0.480 & -0.822 & -0.928 \\
\hline \multicolumn{11}{|l|}{ Bioilsa N12.5 } \\
\hline 0.000 & $2.189 \mathrm{~b}$ & $11.490 \mathrm{a}$ & $0.274 \mathrm{a}$ & $0.235 \mathrm{~cd}$ & $0.253 \mathrm{~d}$ & $0.614 \mathrm{a}$ & $0.923 b c$ & $1.238 \mathrm{a}$ & $2.132 b$ & $2.210 \mathrm{~b}$ \\
\hline 0.166 & $2.400 \mathrm{~b}$ & $11.530 \mathrm{a}$ & $0.260 \mathrm{ab}$ & $0.224 \mathrm{~cd}$ & $0.253 \mathrm{~d}$ & $0.440 \mathrm{bc}$ & $1.341 \mathrm{a}$ & $1.028 \mathrm{~b}$ & $1.828 \mathrm{~cd}$ & $2.486 a$ \\
\hline 1.660 & $2.267 \mathrm{~b}$ & $11.378 \mathrm{a}$ & $0.237 b c$ & $0.216 \mathrm{~cd}$ & $0.272 \mathrm{~d}$ & $0.389 \mathrm{bcd}$ & $0.903 \mathrm{bc}$ & $1.011 \mathrm{~b}$ & $1.777 \mathrm{de}$ & $2.156 b$ \\
\hline 16.60 & $1.249 \mathrm{c}$ & $11.032 \mathrm{a}$ & $0.219 \mathrm{~cd}$ & $0.211 \mathrm{~d}$ & $0.468 \mathrm{ab}$ & $0.308 \mathrm{~cd}$ & $0.439 \mathrm{~d}$ & $0.850 \mathrm{c}$ & $1.695 \mathrm{e}$ & $1.891 \mathrm{c}$ \\
\hline Average & 2.026 & 11.358 & 0.248 & 0.222 & 0.312 & 0.438 & 0.902 & 1.032 & 1.858 & 2.186 \\
\hline$r$ & -0.983 & -0.979 & -0.832 & -0.725 & 1.000 & -0.716 & -0.856 & -0.796 & -0.619 & -0.833 \\
\hline
\end{tabular}

$r$ Pearson's linear correlation coefficient

Homogeneous groups were marked with the same letters separately for each group of enzymes and the type of fertilizing substance

the process of degradation can be impaired by lower availability or total disappearance of nutrients that are necessary for the proper functioning of microorganisms (Kanissery and Sims 2011). Biostimulation is a treatment that allows for an enhancement in the rate of fungicide decomposition. The activity of microorganisms naturally occurring in the soil ecosystem (Adams et al. 2015) is stimulated by nutrients (e.g. compost, manure, or straw) introduction into the soil. The results of the current study indicated (Table 9) that the type of fertilizing substance affected the degradation of chlorothalonil the most (up to $85 \%$ ). In loamy sand without fertilizers (Fig. 4), chlorothalonil was degraded in $70 \%$ after 19 days of the experiment, while in sandy loam in $80 \%$. The introduction of Bioilsa N 12.5 into the soil proved to be effective in chlorothalonil transformation in both types of soil. Degradation of chlorothalonil as a result of soil supplementation with this preparation accounted for $84 \%$ in the loamy sand and for $87 \%$ in the sandy loam. In contrast, Lignohumat Super was ineffective in chlorothalonil degradation. It was observed that chlorothalonil was degraded slower after Lignohumat Super application. The reason for this was a high content of humic substances (90\%), which, similarly as loam minerals, are characterized by a high sorption capacity, which is associated with the ability to retain pollutants, such as pesticides. Chlorothalonil sorbed by humic substances became less accessible to microorganisms, and thus was degraded slower in the soil environment (Cycoń et al. 2009). This fungicide strongly bound to humic acids present in the Lignohumat Super preparation, thus it did not undergo desorption and remained longer in the soil environment (Banach-Szott et al. 2014). In loamy sand, the active substance was degraded in $67 \%$, while in sandy loam in $62 \%$. In the study of Singh et al. (2010), the addition of compost into the soil contributed to the fastest transformation of azoxystrobin. However, azoxystrobin was more rapidly transformed in sandy loam than in loamy sand. These studies prove, that degradation of fungicides depends both on their stability in the soil and on soil particle size. 

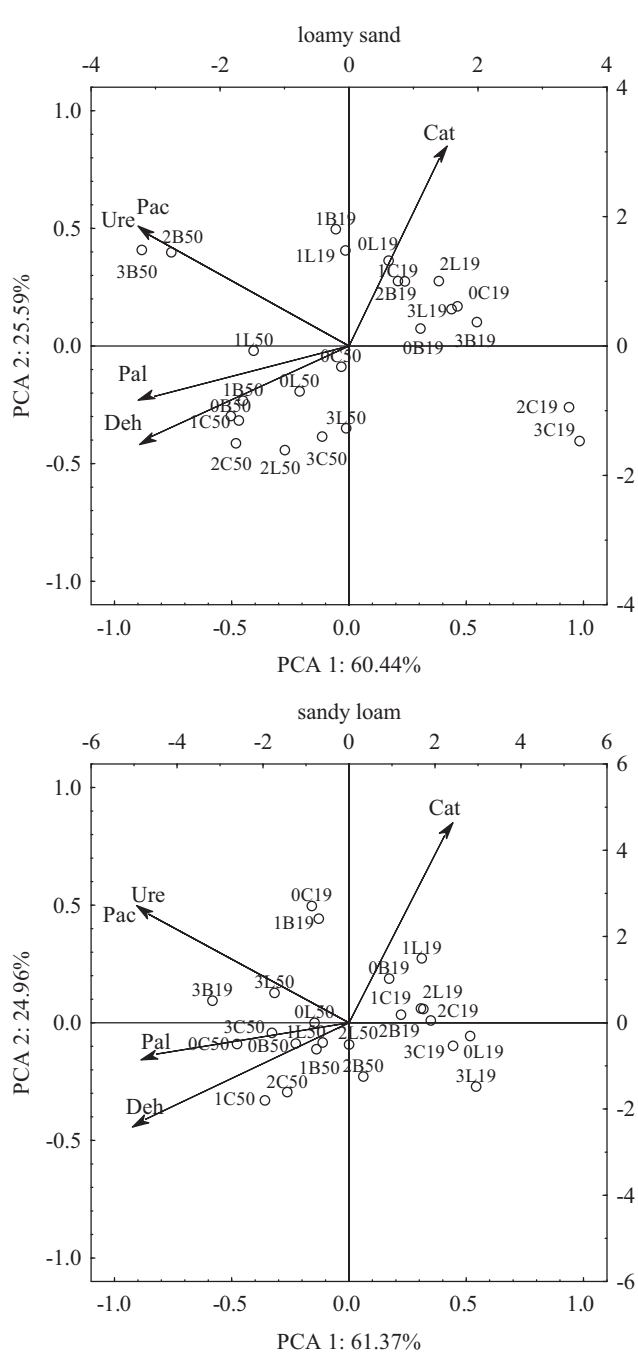

Fig. 3 Enzyme activities in the soil treated with chlorothalonil with the addition of fertilizing substance. Enzymes: Deh dehydrogenases, Cat catalase, Ure urease, Pac acid phosphatase, Pal alkaline phosphatase; dose of fungicide ( $\mathrm{mg} \mathrm{kg}^{-1} \mathrm{DM}$ of soil): 0 soil without the addition of fungicides, $1-0.166 \mathrm{mg}, 2-1.660 \mathrm{mg}, 3-16.60 \mathrm{mg}$; fertilizing substance: $\mathrm{C}$ soil without fertilizing substance addition, $\mathrm{L}$ soil with the addition of Lignohumat Super, B soil with the addition of Bioilsa N 12.5; date of analysis: 19-19 days, 50-50 days

Table 9 The percentage of the observed $\eta^{2}$ variability of the effect of the analyzed factors on the degradation of chlorothalonil applied to the soil at a dose of $16.60 \mathrm{mg} \mathrm{kg}^{-1} \mathrm{DM}$ of soil (two-way analysis of variance, ANOVA, at $P<0.05$ )

\begin{tabular}{lllll}
\hline Parameter & S & Cs & S $\times$ Cs & Error \\
\hline Residues of chlorothalonil & 9.430 & 84.762 & 2.217 & 3.591 \\
\hline
\end{tabular}

$S$ type of soil, $C s$ fertilizing substance

\section{Spring wheat development}

Three-way analysis of variance ANOVA (Table 10) showed a significant effect of fungicide dose and soil type on spring wheat yield. The dose of chlorothalonil influenced yielding

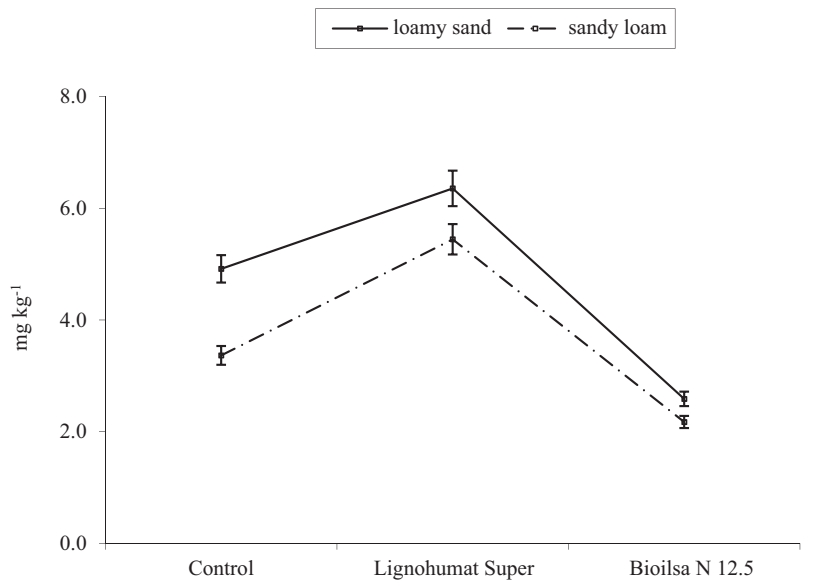

Fig. 4 Chlorothalonil residues in the soil applied at a dose of $16.60 \mathrm{mg}$ $\mathrm{kg}^{-1}$ (mg kg${ }^{-1} \mathrm{DM}$ of soil)

of spring wheat in $39 \%$, and the type of soil in $19 \%$. The introduction of fertilizing substances to the soil had no significant influence on the growth of the tested plant. Fungicides are effective and widely used agricultural chemicals for the control of fungal pathogens in crop plants. However, they can exert a negative impact on plant physiology, mainly through changes in the lipid, protein, chlorophyll or nucleic acid structures. This, in turn, leads to plant growth inhibition and yield reduction (Dias 2012; Petit et al. 2012). The fungicide dose of $16.60 \mathrm{mg} \mathrm{kg}^{-1}$ had the highest inhibitory effect on Triticum aestivum L., as it reduced its yield by $16 \%$ in loamy sand and by $8 \%$ in sandy loam (Table 11). The dose recommended by the manufacturer caused no significant changes in plant growth. Spring wheat exhibited varied sensitivity to chlorothalonil, as evidenced by the resistance index (Fig. 5). Triticum aestivum L. was the most resistant in the objects with chlorothalonil addition in the dose of $0.166 \mathrm{mg} \mathrm{kg}^{-1}$. The mean value of the RS was 0.865 in loamy sand, while 0.946 in sandy loam. The sensitivity of spring wheat increased with fungicide dose, regardless of soil type. However, spring wheat was more resistant to chlorothalonil soil contamination in sandy loam than in loamy sand. This could result from such properties of soil as organic matter content and loam fraction content, and from soil $\mathrm{pH}$, which largely affect pesticides stability in the soil environment. Soils with a higher content of organic matter and the loam fraction are capable to adsorb pesticides in soil colloids, which intensifies their degradation. Pesticides adsorbed by soil colloids are unavailable to root hairs of plant, and thereby are less toxic (Cycoń et al. 2009; Przybulewska and Sienicka 2008). Degradation of pesticides is also more intensive in the soil with $\mathrm{pH}-7$, whereas below this value it is slowed down. In addition, the impact of soil $\mathrm{pH}$ on degradation of pesticides depends, to a large extent, on their susceptibility to alkaline 
Table 10 The percentage of the observed $\eta^{2}$ variability of the effect of the analyzed factors on spring wheat yield (three-way analysis of variance, ANOVA, at $P<0.05$ )

\begin{tabular}{lllllllll}
\hline Parameter & $\mathrm{D}$ & $\mathrm{S}$ & $\mathrm{Cs}$ & $\mathrm{D} \times \mathrm{S}$ & $\mathrm{D} \times \mathrm{Cs}$ & $\mathrm{S} \times \mathrm{Cs}$ & $\mathrm{D} \times \mathrm{S} \times \mathrm{Cs}$ & Error \\
\hline Yield & 39.421 & 18.791 & 2.088 & 8.491 & 9.858 & 5.106 & 6.368 & 9.876
\end{tabular}

$D$ dose of fungicide, $S$ type of soil, $C s$ fertilizing substance
Table 11 Spring wheat yield, $\mathrm{g} \mathrm{pot}^{-1} \mathrm{DM}$ of soil

\begin{tabular}{lll}
\hline Dose of fungicide $\left(\mathrm{mg} \mathrm{kg}^{-1}\right)$ & Loamy sand & Sandy loam \\
\hline Soil without fertilizing substance addition & \\
0.000 & $18.125 \mathrm{a}$ & $16.600 \mathrm{ab}$ \\
0.166 & $17.750 \mathrm{ab}$ & $16.350 \mathrm{ab}$ \\
1.660 & $16.050 \mathrm{ab}$ & $16.275 \mathrm{ab}$ \\
16.60 & $15.275 \mathrm{bc}$ & $15.325 \mathrm{bc}$ \\
Average & 16.800 & 16.138 \\
$r$ & -0.806 & -0.982 \\
Lignohumat Super & & \\
0.000 & $15.850 \mathrm{bc}$ & $15.375 \mathrm{bc}$ \\
0.166 & $17.000 \mathrm{ab}$ & $14.950 \mathrm{c}$ \\
1.660 & $17.525 \mathrm{a}$ & $14.725 \mathrm{c}$ \\
16.60 & $14.975 \mathrm{c}$ & $14.250 \mathrm{c}$ \\
Average & 16.338 & 14.825 \\
$r$ & -0.744 & -0.858 \\
Bioilsa N 12.5 & & \\
0.000 & $17.625 \mathrm{ab}$ & $16.025 \mathrm{ab}$ \\
0.166 & $17.650 \mathrm{ab}$ & $16.100 \mathrm{ab}$ \\
1.660 & $15.600 \mathrm{bc}$ & $15.750 \mathrm{bc}$ \\
16.60 & $15.150 \mathrm{bc}$ & $15.700 \mathrm{bc}$ \\
Average & 16.506 & 15.894 \\
$r$ & -0.750 & -0.716 \\
\hline
\end{tabular}

$r$ Pearson's linear correlation coefficient

Homogeneous groups were marked with the same letters
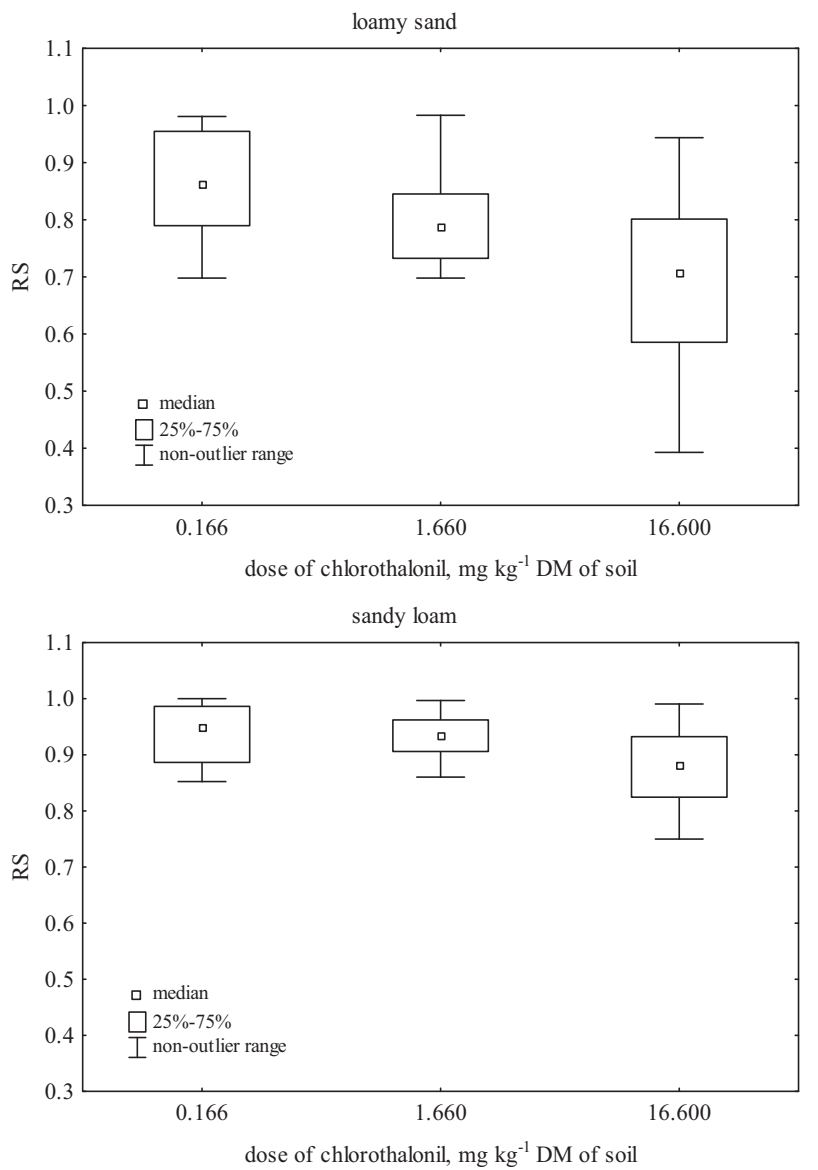

Fig. 5 Effect of chlorothalonil on spring wheat resistance (RS)

\section{Conclusions}

The present study showed that chlorothalonil impacted microbiological and biochemical activity in soil. It stimulated the counts of heterotrophic bacteria and actinobacteria in both loamy sand and sandy loam, while its inhibitory effect was found for fungi. Chlorothalonil also affected soil biochemical properties. It proved to be a inhibitor of acid phosphatase, catalase and dehydrogenase activities. Chlorothalonil exerted variable effects on urease and alkaline phosphatase activities. Spring wheat was also sensitive to excessive quantities of the tested formulation. It should be stressed, however, that the negative effects of the fungicide on soil biological properties were observed in the case of doses many times exceeding the recommended one. Lignohumat Super and Bioilsa N 12.5 fertilizing substances were used to alleviate the negative impact of chlorothalonil 
on the microbiological and biochemical properties of the soil. Soil supplementation with these preparations had a varied impact on soil biological activity, but they were more effective in loamy sand. Fertilizing substances had no significant influence on the yielding of spring wheat. However, soil biostimulation with Bioilsa N 12.5 accelerated chlorothalonil degradation in the soil compared to the soil without the addition of the fertilizing substance. In contrast, Lignohumat Super was ineffective in degrading the tested fungicide, as the active substance was transformed more slowly after its application than in the control soil. To recapitulate, it may be concluded that irrespective of soil type (loamy sand or sandy loam), chlorothalonil used in the optimal dose causes no changes in the biological homeostasis of soil, while when applied in doses multiply exceeding the optimal dose it disturbs the soil microbiota. Finally, Bioilsa N 12.5 turned out to be more effective in restoring soil fertility than Lignohumat Super was.

Acknowledgements Scientific research was financed by the Ministry of Science and Higher Education funds for statutory activity.

\section{Compliance with ethical standards}

Conflict of interest The authors declare that they have no conflict of interest.

Open Access This article is distributed under the terms of the Creative Commons Attribution 4.0 International License (http://crea tivecommons.org/licenses/by/4.0/), which permits use, duplication, adaptation, distribution, and reproduction in any medium or format, as long as you give appropriate credit to the original author(s) and the source, provide a link to the Creative Commons license, and indicate if changes were made.

\section{References}

Adams GO, Fufeyin PT, Okoro SE, Ehinomen I (2015) Bioremediation, biostimulation and bioaugmention: a review. Int J Environ Biorem Biodeg 3(1):28-39

Adekunle IM (2011) Bioremediation of soils contaminated with Nigerian petroleum products using composted municipal wastes. Bioremediat J 15(4):230-241

Arjumend T, Abbasi MK, Rafique E (2015) Effects of lignite-derived humic acid on some selected soil properties, growth and nutrient uptake of wheat (Triticum aestivum L.) grown under greenhouse conditions. Pak J Bot 47(6):2231-2238

Baćmaga M, Kucharski J, Wyszkowska J (2015) Microbial and enzymatic activity of soil contaminated with azoxystrobin. Environ Monit Assess 187:615

Baćmaga M, Wyszkowska J, Kucharski J (2016) The effect of the Falcon 460 EC fungicide on soil microbial communities, enzyme activities and plant growth. Ecotoxicology 25(8):1575-1587

Banach-Szott M, Debska B, Rosa E (2014) Effect of soil pollution with polycyclic aromatic hydrocarbons on the properties of humic acids. J Soils Sediment 14:1169-1178

Bettiol C, De Vettori S, Minervini G, Zuccon E, Marchetto D, Ghirardini AV, Argese E (2015) Assessment of phenolic herbicide toxicity and mode of action by different assays. Environ Sci Pollut Res 23:1-11

Bielińska EJ, Pranagal J (2007) Enzymatic activity of soil contaminated with triazine herbicides. Pol J Environ Stud 16 (2):295-300

Borowik A, Wyszkowska J, Wyszkowski M (2017) Resistance of aerobic microorganisms and soil enzyme response to soil contamination with Ekodiesel Ultra fuel. Environ Sci Poll Res 24:24346-24363

Carter MR (1993) Soil sampling and methods of analysis. Canadian Society of Soil Science, Lewis Publishers, London

Chaudhuri M, Zuhali H, Affam AC (2013) Degradation of pesticide chlorothalonil by visible light-responsive photocatalyst ferrioxalate and $\mathrm{H}_{2} \mathrm{O}_{2}$ under solar irradiation. Int J Photoenergy 1-7

Chaves A, Shea D, Danehower D (2008) Analysis of chlorothalonil and degradation products in soil and water by GC/MS and LC/ MS. Chemosphere 71:629-638

Cycoń M, Wójcik M, Piotrowska-Seget Z (2009) Biodegradation of the organophosphorus insecticide diazinon by Serratia sp. and Pseudomonas sp. and their use in bioremediation of contaminated soil. Chemosphere 76:494-501

Devashree Y, Dutta BK, Paul SB, Choudhury S (2014) The effect of paraquat and fipronil on the soil and rhizosphere microflora of tea (Camellia sinensis (L) O. kuntze). IJIAS 7(4):1534-1543

Dias MC (2012) Phytotoxicity: an overview of the physiological responses of plants exposed to fungicides. J Bot 2012:1-4. https://doi.org/10.1155/2012/135479

García-Gil JC, Kobza J, Soler-Rovira P, Javoreková S (2013) Soil microbial and enzyme activities response to pollution near an aluminium smelter. Clean - Soil, Air, Water 41(5):485-492

Guo P, Zhu L, Wang J, Wang J, Xie H, L D (2015) Enzymatic activities and microbial biomass in black soil as affected by azoxystrobin. Environ Earth Sci 74(2):1353-1361

Hale HK, Fawy HA (2011) Effect of different levels of humic acids on the nutrient content, plant growth, and soil properties under conditions of salinity. Water Air Soil Pollut 6(1):21-29

Handsa A, Kumar V, Anshumali V, Usmani Z (2014) Phytoremediation of heavy metals contaminated soil using plant growth promoting rhizobacteria (PGPR): a current perspective. Rec Res Sci Technol 6(1):131-134

Ijaz M, Mahmood K, Honermeier B (2015) Interactive role of fungicides and plant growth regulator (Trinexapac) on seed yield and oil quality of winter rapeseed. Agronomy 5:435-446

Imfeld G, Vuilleumier S (2012) Measuring the effects of pesticides on bacterial communities in soi: a critical review. Eur J Soil Biol 49:22-30

Janvier C, VilleneuveI F, Alabouvette C, Edel-Hermenn V, Mateille T, Steinberg C (2007) Soil health through soil disease suppression: which strategy from descriptors to indicators? Soil Biol Biochem 39:1-23

Kadian N, Gupta A, Satya S, Mehta RK, Malik A (2008) Biodegradation of herbicide (atrazine) in contaminated soil using various bioprocessed materials. Bioresour Technol 99:4642-4647

Kanissery RG, Sims GK (2011) Biostimulation for the enhanced degradation of herbicides in soil. App Environ Soil Sci 2011:1-10. https://doi.org/10.1155/2011/843450

Kızılkaya R, Akça I, Aşkın t, Yılmaz D, Olekhov V, Samofalova I, Mudrykh N (2012) Effect of soil contamination with azadirachtin on dehydrogenase and catalase activity of soil. Eurasia Soil Sci 2:98-103

Kucharski J, Tomkiel M, Baćmaga M, Borowik A, Wyszkowska J (2016) Enzyme activity and microorganisms diversity in soil contaminated with the Boreal 58 WG herbicide. J Environ Sci Health B 51(7):446-454

Leitao S, Cerejeira MJ, Van den Brink PJ, Sousa JP (2014) Effects of azoxystrobin, chlorothalonil, and ethoprophos on the 
reproduction of three terrestrial invertebrates using a natural Mediterranean soil. Appl Soil Ecol 76:124-131

Łozowicka B, Kaczyński P, Wolejko E, Piekutin J, Sagitov A, Toleubayev K, Isenova G, Abzeitova E (2016) Evaluation of organochlorine pesticide residues in soil and plants from East Europe and Central Asia. Desalin Water Treat 57:1310-1321

Milenkovski S, Bååth E, Lindgren PE, Berglund O (2010) Toxicity of fungicides to natural bacterial communities in wetland water and sediment measured using leucine incorporation and potential denitrification. Ecotoxicology 19:285-294

Mohiuddin M, Mohammed MK (2013) Influence of fungicide (carbendazim) and herbicides (2, 4-D and metribuzin) on non-target beneficial soil microorganisms of Rhizospheric soil of tomato crop. J Environ Sci Toxicol. Food Technol 5(1):2319-2399

Muñoz-Leoz B, Ruiz-Romera E, Antigüedad I, Garbisu C (2011) Tebuconazole application decreases soil microbial biomass and activity. Soil Biol Biochem 43:2176-2183

Murali O, Mehar SK (2014) Bioremediation of heavy metals using spirulina. Int J Geo Earth Env Sc 4(1):244-249

Oleszczuk P, Jośko I, Futa B, Pasieczna-Patkowska S, Pałys E, Kraska $P$ (2014) Effect of pesticides on microorganisms, enzymatic activity and plant in biochar-amended soil. Geoderma 214-215:10-18

Orwin KH, Wardle DA (2004) New indices for quantifying the resistance and resilience of soil biota to exogenous disturbance. Soil Biol Biochem 36:1907-1912

Petit A, Fontaine F, Vatsa P, Clément C, Vaillant-Gaveau N (2012) Fungicide impacts on photosynthesis in crop plants. Photosynth Res 111:315-326

Pimmata P, Reungsang A, Plangklang P (2013) Comparative bioremediation of carbofuran contaminated soil by natural attenuation, bioaugmentation and biostimulation. Int Biodeter Biodegr 85:196-204

Przybulewska K, Sienicka K (2008) Decomposition of atrazine by microorganisms isolated from long-term herbicide experiment soil. Ecol Chem Eng S 15(4):479-487

Saha A, Pipariya A, Bhaduri D (2016) Enzymatic activities and microbial biomass in peanut field soil as affected by the foliar application of tebuconazole. Environ Earth Sci 75:558

Shahgholi H (2014) Factors controlling degradation of pesticides in the soil environment: a review. Agric Sci Dev 3(8):273-278

Shi XZ, Guo RJ, Takagi K, Miao ZQ, Li SD (2011) Chlorothalonil degradation by Ochrobactrum lupini strain TP-D1 and identification of its metabolites. World J Microb Biot 27(8):1755-1764

Singh N, Singh SB, Mukerjee I, Gupta S, Gajbhiye VT, Sharma PK, Goel M, Dureja P (2010) Metabolism of 14C-azoxystrobin in water at different pH. J Environ Sci Health B 45:123-127
Sopeña F, Bending GD (2013) Impacts of biochar on bioavailability of the fungicide azoxystrobin: A comparison of the effect on biodegradation rate and toxicity to the fungal community. Chemosphere 91:1525-1533

Srinivasulu M, Rangaswamy V (2013) Influence of insecticides alone and in combination with fungicides on enzyme activities in soils. Int J Environ Sci Technol 10(2):341-350

Statsoft, Inc, Statistica. (2017) Data Analysis Software System, version 12.5. http://www.statsoft.com.

Stefani Jr A, D’Arc Felício J, de Andréa MM (2012) Comparative assessment of the effect of synthetic and natural fungicides on soil respiration. Sensors 12:3243-3252

Sułowicz S, Piotrowska-Seget Z (2016) Response of microbial communities from an apple orchard and grassland soils to the firsttime application of the fungicide tetraconazole. Ecotox Environ Safe 124:19-201

Tejada M, Gómez I, Garcia-Martinez AM, Osta P, Parrado J (2011) Effects of prochloraz fungicide on soil enzimatic activities and bacterial communities. Ecotox Environ Safe 74:1708-1714

Tomkiel M, Baćmaga M, Wyszkowska J, Kucharski J, Borowik A (2015) The effect of carfentrazone-ethyl on soil microorganisms and soil enzymes activity. Arch Environ Prot 41(3):3-10

Trckova M, Matlova L, Dvorska L, Pavlik I (2004) Kaolin, bentonite, and zeolites as feed supplements for animals: health advantages and risks. Vet Med - Czech 49(10):389-399

Walia A, Mehta P, Guleria S, Chauhan A, Shirkot CK (2014) Impact of fungicide mancozeb at different application rates on soil microbial populations, soil biological processes and enzyme activities in soil. World J 2014:1-9. https://doi.org/10.1155/2014/ 702909

Wang G, Liang B, Li F, Li S (2011) Recent advances in the biodegradation of chlorothalonil. Curr Microbiol 63:450

Wang X, Song M, Gao C, Dong B, Zhang Q, Fang H, Yu Y (2009) Carbendazim induces a temporary change in soil bacterial community structure. J Environ Sci 21:1679-1683

Wu X, Cheng L, Cao Z, Yu Y (2012) Accumulation of chlorothalonil successively applied to soil and its effect on microbial activity in soil. Ecotox Environ Safe 81(1):65-69

Ye X, Dong F, Lei X (2018) Microbial resources and ecologymicrobial degradation of pesticides. Nat Resour Conserv Res 1(1) 22-28

Yen JH, Chang JS, Huang PJ, Wang YS (2009) Effects of fungicides triadimefon and propiconazole on soil bacterial communities. J Environ Sci Health B 44:681-689

Yu YL, Shan M, Fang H, Wang X, Chu XQ (2006) Responses of soil microorganisms and enzymes to repeated applications of chlorothalonil. J Agric Food Chem 54(26):10070-10075 